\title{
Influence of silver nitrate and copper sulphate on somatic embryogenesis, shoot morphogenesis, multiplication and associated physiological biochemical changes in Gladiolus hybridus $L$.
}

Tasiu Isah ( $\nabla$ taasmore@yahoo.co.uk)

Jamia Hamdard https://orcid.org/0000-0002-2112-530X

Qurratul .

Hamdard University New Delhi

Shahid Umar

Hamdard University New Delhi

\section{Research Article}

Keywords: Ornamental plants, Plant growth regulators, Embryogenic callus, Silver nitrate, Copper sulphate, Antioxidants.

Posted Date: February 16th, 2022

DOI: https://doi.org/10.21203/rs.3.rs-1312606/v1

License: (c) (1) This work is licensed under a Creative Commons Attribution 4.0 International License.

Read Full License 


\section{Abstract}

Micronutrients are essential for in vitro plant tissue growth, and studying their culture medium levels manipulation to promote growth and morphogenesis is essential in plant tissue culture experiments. In the present study, influence of $\mathrm{CuSO}_{4} \cdot 5 \mathrm{H}_{2} \mathrm{O}(0-15 \mu \mathrm{M}), \mathrm{AgNO}_{3}(0-60 \mu \mathrm{M})$ and their combinations on callus induction and various morphogenic processes at different treatment levels were studied in $G$. hybridus. $\mathrm{AgNO}_{3}$ was more efficient in promoting the parameters studied, with $40 \mu \mathrm{M}$ been more efficient over other treatment levels tested. In the case of $\mathrm{CuSO}_{4} \cdot 5 \mathrm{H}_{2} \mathrm{O}$ treatments, maximum efficiency was achieved with $7.5 \mu \mathrm{M}$ over other concentration treatment of the tissues analysed. Results of the experiments on morphogenesis and associated physiological biochemical changes suggests that combined treatment with the two metals promoted morphogenesis at higher levels through influence on physiological biochemical changes essential for the morphogenic parameters studied. Application of the technique on embryogenic tissue formation and somatic embryos differentiation seems of appropriate application when using metals for the experiment.

\section{Introduction}

In vitro plant regeneration is influenced by culture medium nutrients with micronutrients regarded indispensable composition of many enzyme molecules involved in physiological biological processes essential for plant development (Maksymiec 1997; Niedz and Evens 2007). Physiological molecular aspects of the plant in vitro morphogenesis have been investigated in several species and varieties (Ramage and Williams 2002; Dalton 2020). However, limited information is known about the influence of nutritional composition of culture medias to morphogenic processes in plants. Pioneer studies on the importance of organic and inorganic nutrients to in vitro plant development were performed by Murashige and Skoog (1962). Since then, it has become increasingly understood that constituents of basal medium and accuracy in their concentration are important for proper plant growth, development and morphogenesis in plant tissue culture experiments (Preece 1995; Mahendra and Dutta Gupta 2004; Dalton 2020).

Inorganic constituents of nutrients in MS medium formulation offer variables for studying the influence of elemental composition on in vitro morphogenic potential of plants (Kothari-Chager et al. 2008; Silvestri et al. 2018). Micronutrients are regarded indispensable components of enzyme molecules, and serve as secondary messengers involved in regulating physiological biochemical pathways associated with the control of in vitro plant tissue growth (Maksymiec 1997; Niedz and Evens 2007). However, literature reports in this respect is on minerals uptake and their physiological nutritional role in plant development rather than morphogenesis.

Metal ions needed by plants in trace quantity for normal growth and development play roles in nucleic acid metabolism and redox reactions or as structural configuration of many enzyme molecules. Higher cellular concentration of the metal ions may affect metabolic processes, resulting in growth inhibition through cellular toxicity (Zenk 1996). Copper sulphate $\left(\mathrm{CuSO}_{4}\right)$ is among the compositions of MS 
medium that serve as principal source of copper $(\mathrm{Cu})$, a transitional metal having two oxidation states $\left(\mathrm{Cu}^{2+}\right)$ under normal physiological growth condition. It is regarded the most crucial micronutrient essential for plant growth and development but, the concentration in growth medium needs optimization for enhanced performance (Lipman and Mackinney 1931; Arnon and Stout 1939). Because of the broadspectrum anti-microbial activity of $\mathrm{Cu}$, its supplementation in the in vitro growth medium of plants could promote multiplication with substantial reduction in infection frequency due to endogenous latent microbes (Javed et al. 2017; Kim et al. 2017; Silvestri et al. 2019). Although optimum physiological requirement of the Cu varies with plant species (Clemens 2001), increased concentration is promotory to shoot morphogenesis through the crucial role it plays in metabolic processes in cells (Delhaize et al. 1985; Droppa and Horvath 1990; Javed et al. 2017). This may be achieved through enhancement in photosynthesis, respiration, antioxidants reactions, hormones biosynthesis, and for perceptions essential for plant growth under the in vitro condition (Nomura et al. 2015; Penarrubia et al. 2015). It was estimated that about $50 \%$ of the copper found in plants is associated with chloroplast and bound to plastocyanin that function in cells as mediator of electron transfer between photosystems (PS) I and II (Weigel et al. 2003). While it is an integral part of photosynthetic machinery, been present in thyllakoids, high levels inhibit PS II and associated enzymes of chlorophyll (Chl) biosynthesis (Moustakas et al. 1994; SanchezViveros et al. 2011). Inhibition of the photosynthesis through Chl biosynthesis may result in damage to membrane permeability with overall effect on cellular physiological metabolic processes disturbance (Shioi et al. 1978; Baszynski et al. 1982). Further, due to its redox activity, higher concentration of free copper ions may cause cellular toxicity that must be regulated during in vitro uptake through regulation of Cu transporters to economize deficiency via transcriptional and post-transcriptional regulation (Burkhead et al. 2009; Ravet and Pilon 2013). Hence, in compliance with the laws of minimum and physiological nutritional tolerance (Good 1931; Shelford 1913, 1931) optimal and cellular tolerable range of copper concentration exists when supplemented above the standard culture medium formulation levels.

Because of its stability, availability, specificity and solubility in water and as potent inhibitor of ethylene, silver nitrate $\left(\mathrm{AgNO}_{3}\right)$ is used in plant cell, tissue and organ culture (PCTOC) experiments for the crucial role it plays in regulating plant physiological processes essential for in vitro plant morphogenesis. Among the physiological processes influenced by the silver ions includes polyamines biosynthesis, ethylene and calcium-mediated biochemical pathways and morphogenesis (Kumar et al. 2009a). Silver nitrate or in the form of silver thiosulphate, has been reported to influence in vitro morphogenesis in many tissue culture experiments but, mechanism of the promotion is unclear (Eapen and George 1997; Bais et al. 2000, 2001; Kim et al. 2017). Evidences have suggested its interfering effect on ethylene perception due to water solubility and lack of cellular toxicity when effective concentration is used (Beyer 1976a, b; Kumar et al. 2009a). Interactive effect of the silver occurs through displacement of the active site of copper at receptor complex to cause opposite effect that results into stable physiological processes essential for enhancement of in vitro morphogenesis (Kumar et al. 2009a). In the plant cells, $\mathrm{Ag}^{+}$(dissolved in $\mathrm{AgNO}_{3}$ ) may react with compounds (such as DNA, RNA, amino acids and lipopolysaccharides) to form silver nanoparticles that may form bond(s) with many biotic receptors to become geno- or cytotoxic (Ratte 1999; Park et al. 2010; Yin et al. 2011). Therefore, cells are sensitive to non-toxic low concentration of $\mathrm{Ag}^{+}$ 
for which the metal ions interferes with auxin and ethylene signaling to make its increased use in plant tissue culture experiment for the regulation of plant developmental processes (Strader et al. 2009; Steinitz et al. 2010; Parimalan et al. 2011). Silver (nitrate) is also higly used as inhibitor of ethylene and its interactive effect on Cu may result in the displacement of $\mathrm{Cu}$ in the active site of receptors in cells (Ciardi and Klee 2001). Basal salts and vitamins present in the PCTOC medias also contain chlorine and addition of $\mathrm{AgNO}_{3}$ to them results in the formation of $\mathrm{AgCl}$ precipitate (Murashige and Skoog 1962; Caldas et al. 1990; Steinitz et al. 2010). Over time, the silver in its particulate form may become released into aqeous solution in the form of $\mathrm{Ag}^{+}$for uptake in plant cells to improve cellular processes essential for plant growth and development in the in vitro condition that in the overall reflects biomass yield (Kittler et al. 2010; Liu et al. 2010). There have been increasing interest on the use of metal nanoparticles in nutrients medias in singularity or combinations to promote morphogenesis in the in vitro culture of plants (Kim et al. 2017; Malik et al. 2021).

Gladiolus hybridus, the 8th most valuable cut flower perrennial bulbous plant belonging to Iridaceae and native to Africa is cultivated for its moderate to long vase-life and beautiful spikes (Memon et al. 2016). Its estimated annual sales was reported to be around 370 million corms cultivated in over 130.000 ha (Narain 2004; Singh 2011) with the low propagation method predominantly been vegetative using corms and cormlets, and seeds used only for raising hybrid varieties (Memon et al. 2016). Plant tissue culture techniques offer alternative propagation method for mass production of G. hybridus enmasse (Ziv et al. 1970; Memon et al. 2016) in particular, when physiological growth requirements could be optimized with the help of knowledge on nutritional physiological factors regulating biomass production under the in vitro culture conditions (Bidabadi and Jain 2020). However, in most reported experimental literatures on the morphogenesis studies of plant species, only one medium is used for duration of a study, a limitation that does not permit complete nutritional characterisation of the physiological optimum growth requirement of different in vitro developmental stages of cultures. Although studies were conducted on different applications of PCTOC for enhanced biomass production in members of the genus Gladiolus (Memon 2012; Memon et al. 2012, 2016), physiological growth requirement of nutrients medium have not been investigated. In the present study, influence of copper sulphate $\left(\mathrm{CuSO}_{4} \cdot 5 \mathrm{H}_{2} \mathrm{O}\right)$ and $\mathrm{AgNO}_{3}$ on callus induction, somatic embryogenesis (SE), shoot biomass production and physiological biochemical changes associated with the morphogenic processes of G. hybridus were assessed.

\section{Materials And Methods}

\section{Explants collection, surface sterilization and cultures establishment}

Healthy G. hybridus corms were obtained from the Horticultural Society of India Calcutta West Bengal (India), its outer coverings removed, washed with cetrimide for about 15 mins and then under running tap water for 3 mins. Thereafter, obtained corms were treated with 70\% ethanol for 5 mins and rinsed with sterile distilled water three (3) times. Corms were surface sterilized with mercuric chloride $(0.05 \%)$ for 3 
mins and rinsed with sterile distilled water 3-4 times to remove traces of the $\mathrm{HgCl}_{2}$. Surface sterilized corms were longitudinally sliced into 5-10 mm explant pieces before cultured on solid MS medium supplemented with 2,4-D (4.52 $\mu \mathrm{M})$, sucrose $(3 \%)$ and inositol $\left(100 \mathrm{mg} \mathrm{L}^{-1}\right)$ for callus induction. Media $\mathrm{pH}$ were adjusted to 5.7 before autoclaved at $10321.35 \mathrm{pa}$ and $121^{\circ} \mathrm{C}$ for $15 \mathrm{mins}$. The induced callus cultures were proliferated on control MS medium amended with 2,4-D $(4.52 \mu \mathrm{M}), \mathrm{BAP}(2.22 \mu \mathrm{M})$ and BAP + NAA $(8.88+1.35 \mu \mathrm{M})$ until brownish embryogenic callus formation characterised by near globular or elongated and cylindrical structures on callus surface was observed (Mujib et al. 2017). The number of embryos induced on the callus surface and their proliferation increased with increase in the culture duration but, data were taken after 4 weeks cultivation for each. Proliferated somatic embryos were transferred to maturation medium amended with $\mathrm{GA}_{3}(2.60 \mu \mathrm{M})$ where the embryos elongated before germination on medium added with BAP $(2.22 \mu \mathrm{M})$. Recovered plantlets were transferred to medium supplemented with IBA $(4.84 \mu \mathrm{M})$ for efficient root formation before aclimatization experiment. Effect of $\mathrm{CuSO}_{4}(0.1,2.5,5.0,7.5,10.0,12.5$, and $15.0 \mu \mathrm{M}), \mathrm{AgNO}_{3}(5.0,10,20,30,40,50$ and $60 \mu \mathrm{M})$ and their combinations on callus induction, embryogenic tissue formation and its proliferation, embryos induction, proliferation, maturation and germination, shoot morphogenesis and rhizogenesis of micro shoot (shoot generated on medium without metals amendment) using solid MS medium supplemented with the various PGRs were carriedout. Rooted plantlets were aclimatized in potted mixtures before transferred to the herbal garden (Jamia Hamdard New Delhi, India) field condition.

Fresh stock solutions of the $\mathrm{CuSO}_{4}$ and $\mathrm{AgNO}_{3}$ were prepared by dissolving gram dried weight $(\mathrm{mg})$ of the salts in distilled water, and total concentration in medium volume added during media preparation. All cultures were kept under cultures incubation room temperatures of $25 \pm 1^{\circ} \mathrm{C}$ and $16 \mathrm{~h}$ photoperiod provided by cool white fluorescent lamps of $100 \mu \mathrm{mol} \mathrm{m}^{-2} \mathrm{~s}^{-1}$ photon flux density (Phillips, India).

\section{Callus induction frequency $(\%)=\underline{\text { No. of explants cultured }} \times 100$}

No. of explants transformed into callus

\section{Embryogenic potential per culture tube (Number of embryos $\mathbf{g}^{-1}$ of callus) $=$ \\ Number of embryos per culture tube (number of embryos in $\mathrm{g}^{-1}$ of sample $\mathrm{X}$ total weight of embryos per culture tube $\mathrm{g}$ ) \\ Initial inoculum density $(\mathrm{g})$}

Relative growth rate of cultures $(\%)=$ Percentage of the initial embryogenic callus transferred in culture tube

Number of SEs per gram after 28 days cultivation

Shoot forming capacity $=$ Average number of shoots per regenerating callus mass $\left(\mathrm{g}^{-1}\right)$

$\mathrm{X}$ Percentage of regenerating explant-formed callus (Lambardi et al.

1993) 
Physiological biochemical analysis of tissues

The various tissue biomass were harvested from cultures and prepared for the analysis experiments; details of the methods for physiological biochemical analysis of the various in vitro generated tissues were carriedout as described earlier (Isah and Umar 2018; Isah 2019). Chlorophylls a and b, total chlorophyll (Chl) and carotenoids (Cars) content of the shoot cultures were carriedout as reported by Arnon (1949) and Wellburn (1994). Glycinebetaine content of the shoots were analyzed using calorimetric method (Grieve and Grattan 1983) as modified in Lokhande et al. (2010). In the case of embryogenic tissue, induced embryos, proliferated embryos, mature and germinated embryos, biochemical parameters of proline (Bates et al. 1973), total soluble sugars (Watanabe et al. 2000) as modified by Lokhande et al. (2010), lipid peroxidation via malondialdehyde (MDA) content analysis (Alexieva et al. 2001), superoxide dismutase (SOD) assay (Becana et al. 1986), catalase (CAT) activity (Cakmak and Marscher 1992), ascorbate peroxidase (APX) activity (Nakano and Asada 1981) and guaiacol peroxidase (GPX) activity (Hemeda and Klein 1990) were respectively measured.

\section{Statistical analysis}

Experiments were performed in an arranged complete randomized block design (CRBD) and generated data from triplicate experiments (consisted of 8 replicates per treatment and repeated twice) were analysed using SPSS ver. 21 (USA). Results are presented as means with standard error of the replicated experiments. Significant differences between the treatments were assessed by analysis of variance (ANOVA) followed by a Tukey's range test assessment at probability levels of $p \leq 0.05$.

\section{Results And Discussion}

\section{Shoot morphogenesis and somatic embryogenesis}

Callus was induced from corm explants within two weeks cultivation (Fig. 1a) on solid MS medium amended with 2,4-Dichlorophenoxy acetic acid (2,4-D) $(4.52 \mu \mathrm{M})$ where maximum of $72.66 \%$ callus induction efficiency was achieved. Induced callus cultures were proliferated on solid MS medium amended with the same PGR for two subcultures, with intervals of 3-4 weeks cultivation (Fig. 1a-b). Hard, compact, brownish and semi-brown callus cultures were observed within the proliferated callus mass (Fig. 1C). The different callus masses were sectored to observe their differential morphogenesis on control MS medium and when amended with 2,4-D (4.52 $\mu \mathrm{M}), \mathrm{N}^{6}$-Benzylaminopurine (BAP) $(2.22 \mu \mathrm{M})$ and BAP + Naphthalene acetic acid (NAA) $(8.88+1.35 \mu \mathrm{M})$. After four weeks cultivation, in some of the callus masses, direct shoot differentiation were observed on medium added with BAP but at low frequency (Fig. 1d-e, I-m). On medium amended with the various PGRs, somatic embryos differentiation were similarly observed at variable frequency, with the highest induction been on 2,4-D (4.52 $\mu \mathrm{M})$ where $80.15 \%$ somatic embryos differentiation were observed. This was followed by BAP + NAA $(8.88+1.35$ 
$\mu \mathrm{M})$ that produced $72.87 \%$ somatic embryos and least with the BAP $(2.22 \mu \mathrm{M})$ that recorded $16.23 \%$ efficiency in the embryos induction $(b-d)$. The embryos were oval to roundish, elliptical, in some cases with cotyledonary apex and yellowish radicle primordia at polar end (Fig. b-d). Embryos were proliferated on medium added with BAP and NAA combinations to obtain embryos at different stages of development and for which $14.63 \%$ embryos mass proliferation efficiency was achieved after four weeks cultivation (Fig. b-d). Mature somatic embryos were obtained when cultivated on medium added with Gibberelic acid $\left(\mathrm{GA}_{3}\right)$ level $(2.60 \mu \mathrm{M})$ where $54.67 \%$ and $63.85 \%$ maximum embryos maturation were recorded after four and eight weeks cultivation, respectively. Mature somatic embryos germination frequency was similarly assessed on medium amended with BAP $(2.22 \mu \mathrm{M})$ for which maximum of $42.77 \%$ embryos germination was achieved after six weeks culture. The embryos had weak root system and as such, were cultured on medium added with indole butyric acid (IBA) $(2.42 \mu \mathrm{M})$ for two weeks to facilitate complete roots development before cultured again on medium added with $\mathrm{GA}_{3}$ to facilitate complete embryos germination into plant $(c-p)$.

\section{Influence of copper sulphate and silver nitrate on the in vitro morphogenesis Indirect somatic embryogenesis}

Growth and morphogenesis of plant tissue cultures is influenced by medium composition, and appropriate nutrients levels in the growth medium could serve as substitute to PGRs in promoting tissue growth and possible morphogenesis (Preece 1995; Dahleen and Bregitzer 2002; Silvestri et al. 2018). To study the influence of $\mathrm{CuSO}_{4}$ and $\mathrm{AgNO}_{3}$ on morphogenic processes of indirect $\mathrm{SE}$ pathways, shoot morphogenesis, multiplication and rhizogenesis, various concentrations of the salts were supplemented in MS medium amended with PGRs. Generally, on dry weight (DW) basis, about $2-20 \mathrm{mg} \mathrm{Kg}^{-1}$ Cu content in growth medium is considered beneficial to plant growth while $20-30 \mu \mathrm{g} \mathrm{g}^{-1}$ per dried weigh (DW) of leaves constitute toxicity levels in some plant species (Robson and Reuter 1981). As such, each plant species has its tolerance and minimum range of $\mathrm{Cu}$ physiological utilisation because $\mathrm{Cu}$ is an important constituent of enzymes such as ascorbate, cytochrome, diamine and quinol oxidases, phenolase, SODs and fraction 1 protein involved in protein, carbohydrate biosynthesis and electron transport whose expression is essential in plant regeneration by in vitro culture (Purnhauser and Gyulai 1993). $\mathrm{AgNO}_{3}$ supplementation in growth medium of plants also serves as source of silver ions that may interact with polyamines to promote SE and organogenesis (Zhang et al. 2001) through the S-adenosyl methionine inhibition by the ethylene produced in cultures that ultimately promote polyamines biosynthesis (Roustan et al. 1990; Parimalan et al. 2010). In the present study and on callus induction medium, $\mathrm{AgNO}_{3}$ proved efficient in influencing callus biomass production from cormic explants with $97.37 \%$ efficiency achieved on medium added with $40 \mu \mathrm{M}$ over $\mathrm{CuSO}_{4} \cdot 5 \mathrm{H}_{2} \mathrm{O}$ treatments where maximum of $84.72 \%$ was recorded on medium supplemented with $7.5 \mu \mathrm{M}$. Combinatorial treatment $\left(\mathrm{AgNO}_{3} 40 \mu \mathrm{M}+\mathrm{CuSO}_{4} \cdot 5 \mathrm{H}_{2} \mathrm{O} 7.5 \mu \mathrm{M}\right)$ produced maximum of $98.26 \%$ callus biomass induction frequency over other concentrations tested, suggesting the combinatorial dosage as the most efficient over the other treatments tested (Fig. 2A). Concentration of nutrients in culture medium through interplay with supplemented PGRs have been shown to influence callus induction in several in vitro culture systems of plant species (DeFossard 1974; 
Ramage and Williams 2002). Influence of $\mathrm{AgNO}_{3}$ to callus growth is also species and genotype dependent; it showed none effect on callus production in Zea mays (Vain et al. 1989) but, promoted callus growth in Triticum aestivum (Wu et al. 2006). In ragi and kodo crop callus cultures, increase in $\mathrm{Cu}$ concentration in growth medium up to 50 times the normal culture medium levels improved callus induction, its fresh weight (FW) and plant regeneration while cultures cultivated on medium devoid of $\mathrm{Cu}$ could not regenerate shoot, suggesting the essentiality in plant regeneration (Kothari-Chajer et al. 2008). In the case of Ocimum basilicum, SE and plant regeneration were promoted by moderate levels of $\mathrm{CuSO}_{4}$ supplemented in growth medium while higher proved toxic to the cultures, and resulted in reduction on the parameters studied (Ibrahim et al. 2018). For $\mathrm{AgNO}_{3}(0.6-5.9 \mu \mathrm{M})$, promoted plant regeneration was achieved by 2-3 times and subsequently, efficiency of the treatments were tested on induced callus mass proliferation (Kothari-Chajer et al. 2008). $\mathrm{AgNO}_{3}$ at $40 \mu \mathrm{M}$ proved more efficient on callus proliferation over $\mathrm{CuSO}_{4} .5 \mathrm{H}_{2} \mathrm{O}$ that had its maximum at $7.5 \mu \mathrm{M}$ where $2.59 \pm 0.15 \mathrm{~g}$ and $1.24 \pm 0.18 \mathrm{~g}$ callus mass accumulation were respectively achieved but, combinatorial treatment $\left(\mathrm{AgNO}_{3} 40 \mu \mathrm{M}+\mathrm{CuSO}_{4} \cdot 5 \mathrm{H}_{2} \mathrm{O} 7.5\right.$ $\mu \mathrm{M}$ ) had $3.11 \pm 0.11 \mathrm{~g}$ callus mass as the best treatment results after four weeks cultivation (Fig. $2 \mathrm{~B}$ ).

Inorganic nutrients in $\mathrm{MS}$ medium of $\mathrm{CuSO}_{4} \cdot 5 \mathrm{H}_{2} \mathrm{O}$ and $\mathrm{AgNO}_{3}$ also offer variables for studying nutritional physiological role of metals in morphogenic potential of callus cultures in $G$. hybridus. Irrespective of PGRs amended in the culture medium, callus proliferation and in vitro morphogenesis can be improved through medium salts concentration and composition modification (Ramage and William 2002; Silvestri et al. 2018). In some species, embryogenic response occurs at low frequency and embryos formed may turn out abnormal in structures - with fused or altered number of cotyledons (Nic-Can et al. 2015; Garcia et al. 2019). However, supplementing culture medium with higher levels of $\mathrm{AgNO}_{3}\left(10 \mathrm{mg} \mathrm{L}^{-1}\right)$ was found to promote embryogenic tissue formation and differentiation while lower levels $\left(1.0 \mathrm{mg} \mathrm{L}^{-1}\right)$ promoted asynchrony of embryos, overcomes abnormal embryos differentiation and higher number of mature embryos formation (Kong et al. 2012). In the present study, for the influence on embryogenic tissue formation from proliferated callus cultures, $\mathrm{AgNO}_{3}$ was equally efficient in inducing maximum of $1.28 \pm$ $0.16 \mathrm{~g}$ callus mass within four weeks cultivation on solid MS medium added with $40 \mu \mathrm{M}$ over that of $\mathrm{CuSO}_{4}$ that had $7.5 \mu \mathrm{M}$ as the most efficient with $0.94 \pm 0.18 \mathrm{~g}$ embryogenic callus mass accumulated. Treatment of the callus cultures with the two metals promoted maximum embryogenic callus mass production of $1.74 \pm 0.14 \mathrm{~g}$ on $\mathrm{AgNO}_{3} 40 \mu \mathrm{M}+\mathrm{CuSO}_{4} \cdot 5 \mathrm{H}_{2} \mathrm{O} 7.5 \mu \mathrm{M}$ amended levels, suggesting the concentration as the most efficient for maximum embryogenic tissue formation from proliferated callus mass (Fig. $2 \mathrm{C}$ ). $\mathrm{CuSO}_{4}$ and $\mathrm{AgNO}_{3}$ treatments have promoted embryogenic callus and plant regeneration in many plant species (Purnhauser and Gyulai 1993; Nirwan and Kothari 2003; Kothari et al. 2004; Joshi and Kothari 2007). Embryogenic callus formation, proliferation, embryos differentiation and germination were influenced by $\mathrm{AgNO}_{3}$ amendment in the cultivation medium of Picea glauca (Kang and Yeung 1995), Hedychium muluense (Sakhanokho et al. 2009), Phoenix dactylifera (Diab 2017; Roshanfekrra et al. 2017; Abdolvand et al. 2018) and Coffea species in genotype-dependent manner (Fuentes et al. 2000; Giridhar et al. 2004; Lope-Gomez et al. 2016; Rojas-Lorz et al. 2019) while it influenced shoot morphogenesis in Brassica napus (Uliaie et al. 2008; Cristea et al. 2012). $\mathrm{AgNO}_{3}$ at $10 \mathrm{mg} \mathrm{L}^{-1}$ improved 
the frequency of embryogenic callus formation from immature embryo-induced callus cultures of wheat (Wu et al. 2006).

In the case of somatic embryos induction, obtained embryogenic tissues were treated with concentrations of $\mathrm{AgNO}_{3}, \mathrm{CuSO}_{4} \cdot 5 \mathrm{H}_{2} \mathrm{O}$ and their combination using solid embryo induction medium. Maximum somatic embryos differentiation was achieved on medium amended with $\mathrm{AgNO}_{3}(40 \mu \mathrm{M})$ where $95.72 \%$ embryos production with average of $26.52 \pm 0.17$ embryos induction over $\mathrm{CuSO}_{4} \cdot 5 \mathrm{H}_{2} \mathrm{O}$ where $7.5 \mu \mathrm{M}$ was the most effective on embryos induction efficiency with $16.31 \pm 0.12$ embryos, representing $89.09 \%$ embryos production efficiency. However, compared to singular treatment of the metals, their combination yield maximum number of embryos induction of $28.79 \pm 0.18$, representing $97.31 \%$ success in embryos induction from the embryogenic tissues (Fig. 2D-E). Obtained somatic embryos at different stages of development were proliferated on medium supplemented with BAP and NAA $(8.88+1.35 \mu \mathrm{M}) . \mathrm{AgNO}_{3}$ at moderate levels (up to $50 \mu \mathrm{M}$ ) promoted SE in Coffea canephora (Kumar et al. 2007) and Hedychium

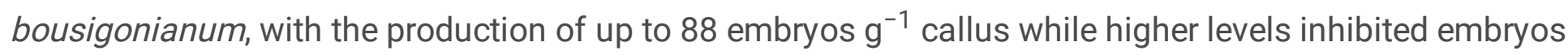
differentiation from embryogenic callus (Sakhanokho et al. 2009). In Daucus carota callus cultures, 5-7 days exposure to $\mathrm{AgNO}_{3}(10-20 \mu \mathrm{M})$ was sufficient in inducing SE at high frequency with 2-fold enhanced embryos formation achieved relative to control cultures (Roustan et al. 1990). Improvement on SE and plant regeneration were achieved from immature embryo-derived callus when cultivation medium of Oryza sativa genotypes were supplemented with 2,4-D $\left(9.0 \mu \mathrm{M} \mathrm{L}^{-1}\right)$ in combination with $\mathrm{CuSO}_{4}(10-50$ $\mu \mathrm{M} \mathrm{L}^{-1}$ ) (Sahrawat and Chand 1999).

To figure the influence of metals on embryos proliferation, somatic embryos were treated with various concentration levels. Maximum efficiency on embryos proliferation was achieved on medium added with $\mathrm{AgNO}_{3}$ at $40 \mu \mathrm{M}$ where $24.16 \pm 0.14$ embryos were produced, representing $96.38 \%$ embryos formation frequency recorded over the maximum for $\mathrm{CuSO}_{4} .5 \mathrm{H}_{2} \mathrm{O}(7.5 \mu \mathrm{M})$ treatment that had $18.21 \pm 0.16$ embryos, representing $89.21 \%$ efficiency. However, combination of the metals gave the best results of $26.52 \pm 0.10$ embryos that represents $97.53 \%$ efficiency (Fig. 2F-G). For maturation treatment of the embryos, $\mathrm{AgNO}_{3}$ at $40 \mu \mathrm{M}$ levels proved more efficient with the production of $70.38 \%$ and $85.21 \%$ after four and eight weeks culture respectively, while $\mathrm{CuSO}_{4} \cdot 5 \mathrm{H}_{2} \mathrm{O}$ at the maximum of $7.5 \mu \mathrm{M}$ treatment produced $63.48 \%$ and $70.24 \%$ respectively. Combination of the two metals in the cultivation medium produced $75.21 \%$ and $87.39 \%$ respectively at $40 \mu \mathrm{M} \mathrm{AgNO}{ }_{3}+7.5 \mu \mathrm{M} \mathrm{CuSO}_{4} .5 \mathrm{H}_{2} \mathrm{O}$ treatment of the embryos (Fig. $2 \mathrm{H}-\mathrm{I}$ ). In embryos germination experiments, maximum germination of mature somatic embryos was achieved on solid MS medium amended with $40 \mu \mathrm{M} \mathrm{\textrm {ANO } _ { 3 }}$ treatment levels with $65.22 \%$ germinated embryos over the maximum of $7.5 \mu \mathrm{M}$ levels of $\mathrm{CuSO}_{4} .5 \mathrm{H}_{2} \mathrm{O}$ that had $54.38 \%$ germinated embryos after six weeks cultivation. Combination of the two metals proved more efficient in facilitating somatic embryos germination, with maximum achieved on $\mathrm{AgNO}_{3} 40 \mu \mathrm{M}+\mathrm{CuSO}_{4} .5 \mathrm{H}_{2} \mathrm{O} 7.5 \mu \mathrm{M}$ amended medium where $68.34 \%$ embryos germination frequency were recorded (Fig. $2 \mathrm{~J}$ ). In other reported studies, embryogenic callus formation, somatic embryos differentiation and germination were promoted when $\mathrm{AgNO}_{3}$ was amended in different cultivation-stage medias of Oryza sativa, with $3 \mathrm{mg} \mathrm{L}^{-1}$ 
been the most efficient concentration over other levels tested while $5 \mathrm{mg} \mathrm{L}^{-1}$ for plant regeneration from callus cultures (Ghobeishavi et al. 2015).

\section{Shoot morphogenesis and multiplication}

Indirect shoot morphogenesis from callus cultures offer alternatives for developing transgenic plants of horticultural importance (Rego and de Faria 2001; de Almeida et al. 2015). However, such reports from callus cultures of ornamental plants are very low, and even in cases where reported occurs at low frequency (Rout et al. 2006; de Almeida et al. 2015). In the present study, callus cultures that showed shoot morphogenesis potential were sectored and cultivated on solid MS medium supplemented with $\operatorname{BAP}(2.22 \mu \mathrm{M})$ and $\mathrm{CuSO}_{4}, \mathrm{AgNO}_{3}$ or their combination amendments (Fig. 1I-m) to study their possible influence on shoot morphogenesis and multiplication (Fig. 1q-u). High levels of $\mathrm{Cu}$ in growth medium of plants had been reported toxic to cell growth that lead to tissue growth inhibition in cultures (Yruela 2005), more particular on shoot length (Verma et al. 2011). In the present study, treatment of callus cultures with the various $\mathrm{AgNO}_{3}$ concentrations promoted maximum shoot morphogenesis on medium supplemented with $40 \mu \mathrm{M}$ over other concentrations tested after six weeks cultivation, with the production of $4.53 \pm 0.13$ shoots. In the case of $\mathrm{CuSO}_{4}$ supplemented medium callus cultivation, $7.5 \mu \mathrm{M}$ proved most efficient with the production of $2.74 \pm 18$ shoots after six weeks cultivation. Combination of the two metals at different concentrations gave the best results on medium added with $\mathrm{AgNO}_{3} 40 \mu \mathrm{M}+$ $\mathrm{CuSO}_{4} \cdot 5 \mathrm{H}_{2} \mathrm{O} 7.5 \mu \mathrm{M}$ where $5.35 \pm 0.23$ shoots morphogenesis was achieved (Fig. 2K). Copper is required at higher concentration for improved plant regeneration from callus cultures (Dahleen 1995). Significant positive effectiveness of $\mathrm{Cu}(1-100 \mu \mathrm{M})$ on the shoot morphogenesis had been reported in wheat, triticale and Nicotiana (Purnhauser and Gyulai 1993) and in several studies with Secale, Sorghum, Wheat and Eleusine (Popelka and Altpeter 2001; Nirwan and Kothari 2003; Kothari et al. 2004; Tahiliani and Kothari 2012; Dalton 2020). MS medium supplemented with $\mathrm{Cu}$ at $1.0 \mu \mathrm{M}$ showed inhibitory effects on shoot regeneration in the in vitro cultures of $F$. vulgare but, optimum number of shoots were regenerated when not supplemented in growth medium of the plants, while other concentrations promoted the morphogenesis at variable degree (Dwivedi et al. 2020). Shoot bud differentiation and elongation was promoted by $\mathrm{CuSO}_{4}$ treatment of callus cultures in Capsicum annuum with the highest response achieved during second stage subculture on medium supplemented with 30 times higher levels of the metal over the standard MS medium concentration while for $\mathrm{AgNO}_{3}$ treatments, $18.0 \mu \mathrm{M}$ was the optimal levels (Joshi and Kothari 2007). It promoted callus induction and shoot morphogenesis from callus cultures of Solanum lycopersicum in explant type, genotype and concentration dependent manner (Shah et al. 2014) while in Zinnia species and Anthurium andraenum genotypes, $\mathrm{AgNO}_{3}$ up to $2.0 \mathrm{mg} \mathrm{L}^{-1}$ promoted shoot morphogenesis, multiplication and quality accompanied with reduction in time needed for rooting and aclimatization of micropropagated plants (Anantasaran and Kanchanapoom 2008; Cardoso 2019). Multiple shoot morphogenesis, elongation and bud enlargement in the same species and in Vigna mungo were enhanced under $\mathrm{AgNO}_{3}$ treatments on the basis of culture stage and subcultures of the cultivated plant tissues (Hyde and Phillips 1996; Mookkan and Andy 2014). In banana tissue cultures, Tamimi and Othman (2020) reported significant increase in shoot multiplication on medium 
supplemented with $\mathrm{CuSO}_{4} \cdot 5 \mathrm{H}_{2} \mathrm{O}$ at varied concentration levels with $6 \mathrm{mg} \mathrm{L}^{-1}$ as the most efficient for which two-fold increase in shoot morphogenesis and elongation was recorded. Because the shoots showed potential for multiple shoot differentiation, the experiment was extended to the possible influence of these metals on multiple shoot morphogenesis. $\mathrm{AgNO}_{3}$ concentrations proved more efficient in multiple shoot differentiation, with the maximum production achieved on solid medium added with 40 $\mu \mathrm{M}$ for which $19.57 \pm 0.12$ shoots were produced over other concentrations tested. For $\mathrm{CuSO}_{4}, 7.5 \mu \mathrm{M}$ proved the most effective with the production of $14.72 \pm 0.19$ shoots after 6 weeks cultivation (Fig. 2L). Combination of the two metals further enhanced multiple shoots differentiation, with the maximum produced by $\mathrm{AgNO}_{3} 40 \mu \mathrm{M}+\mathrm{CuSO}_{4} \cdot 5 \mathrm{H}_{2} \mathrm{O} 7.5 \mu \mathrm{M}$ combinations where $23.54 \pm 0.17$ shoots were produced after six weeks cultivation and over other treatments tested. In reported studies with other species, multiple shoot morphogenesis had been achieved from shoot-tip explants on medium amended with $\mathrm{AgNO}_{3}$ without PGRs supplementation and when in combination with $\mathrm{BAP}$, with the highest response achieved when $11.77 \mu \mathrm{M}$ of the $\mathrm{AgNO}_{3}$ was amended in the cultivation medium, while combination with kinetin could not evoke morphogenic response of the cultures (Ozudogru et al. 2005). $\mathrm{AgNO}_{3}$ treatment of Prosopis cineraria, Brassica napus, Passiflora giberti, Hevea brasiliensis and Mucuna pruriens promoted vigorous dark-green multiple shoot morphogenesis with maximum achieved on medium supplemented with 1-2 $\mathrm{mg} \mathrm{L}^{-1}$ where average of up to 5 shoots/explant were recorded (Sirisom and Te-Chato 2012; Roh et al. 2012; Faria et al. 2017; Venkatachalam et al. 2017; Alam and Anis 2019)

\section{Rhizogenesis}

For rhizogenesis on the optimized root morphogenesis solid MS medium, i.e supplemented with IBA (2.42 $\mu \mathrm{M})$, influence of the two metals on root morphogenesis was studied at the various amended concentration levels (Fig. $1 \mathrm{v}-\mathrm{y} ; 2 \mathrm{M}$ ). Maximum roots morphogenesis was achieved on $\mathrm{AgNO}_{3}$ amended medias over that of the $\mathrm{CuSO}_{4}$ treatments. $\mathrm{AgNO}_{3}$ at $40 \mu \mathrm{M}$ was the most efficient, producing $13.36 \pm$ 0.13 roots per micro shoot over that of the $\mathrm{CuSO}_{4} \cdot 5 \mathrm{H}_{2} \mathrm{O}$ treatments where $7.5 \mu \mathrm{M}$ was the most efficient with $10.42 \pm 0.15$ roots recorded after six weeks cultivation. Combination of the two metals proved more efficient over singular treatment, suggesting synergistic influence response to the various treatments, with the highest achieved on medium added with $\mathrm{AgNO}_{3} 40 \mu \mathrm{M}+\mathrm{CuSO}_{4} \cdot 5 \mathrm{H}_{2} \mathrm{O} 7.5 \mu \mathrm{M}$ over other concentrations tested (Fig. 2M). Stimulatory effect of $\mathrm{AgNO}_{3}$ on root morphogenesis have been reported in several plant species such as Coffea arabica (Giridhar et al. 2003), Routa aquatica (Sunandakumari et al. 2004), Gentiana lutea (Petrova et al. 2011), Musa acuminata (Tamimi 2015) and Prosopis cineraria (Venkatachalam et al. 2017). Also, requirement of Cu for increased lateral roots formation had been demonstrated from the seedlings of Eucalyptus camaldulensis (Dunn et al. 1997). However, high levels of $\mathrm{Cu}$ in growth medium may cause some symptoms such as chlorosis and brown necrosis that may impact root morphogenesis, architecture and biomass production (Marschner 1995; Lequeux et al. 2010).

Influence of silver nitrate and copper sulphate on physiological biochemical changes associated with somatic embryogenesis and shoot morphogenesis

Changes during somatic embryogenesis 
Cellular stress is known to trigger elevation in the production of reactive oxygen species (ROS) that subsequently activate the expression of genes encoding antioxidative enzyme systems as a cellular defensive strategy essential for SE (Gressel and Galum 1994; Arora et al. 2002; Zavattieri et al. 2010; Ochatt and Revilla 2016). Overproduction of the ROS could result into direct cellular damage or formation of secondary toxic substances (Benson 2000) that plants have evolved antioxidant protection systems of SOD, CAT, APX, GPX and MDA for overcoming such challenges (Larson 1988). The role of Cu in ROS generation and for serving as cellular signaling molecules in elevated levels of ROS have been known through its facilitation of morphogenesis, with a reduction in rate of cultures infection (Lamb and Dixon 1997; Javed et al. 2017). Copper-mediated ROS production is facilitated through binding to antioxidant enzymes to reduce their chelating power or reduction in uptake and transport of metals such as zink and iron (Baker and Walker 1990; Lombardi and Sebastian 2005). Higher cellular levels of the Cu could promote generation of free radicals that may cause damage to proteins and other biomolecules in cells (Kumar et al. 2009b). Because $\mathrm{Cu}$ ions reduces the ability of antioxidants to chelate active oxygen species and induce oxidative stress essential for SE, the enzymes are expressed at higher levels to maintain cellular homeostasis (Halliwell and Gutteridge 1984). Similarly, $\mathrm{AgNO}_{3}$ through its ions play modulatory roles on antioxidant defense systems that on the basis of species or genotype activates stress responses essential for in vitro morphogenesis (Al Ramadan et al. 2021). In the present study, influence of $\mathrm{CuSO}_{4} .5 \mathrm{H}_{2} \mathrm{O}, \mathrm{AgNO}_{3}$ and their combinations at different concentration levels on the expression of antioxidant systems during SE were studied through the stages of embryogenic tissue formation and proliferation, somatic embryos induction, proliferation, maturation and germination on solid MS medium amended with various PGRs and their concentration.

Superoxide dismutase, a copper-containing metallo-enzyme, plays critical role in scavenging free radicals in cells and its highest activity is associated with chloroplasts $₫$ photosynthetic reaction centers connected to the cytochrome oxidase (Asada 1977; Shkolnik 1984). It plays prominent role in embryogenic competence acquisition and expression through the activity at high levels that results in generation of $\mathrm{H}_{2} \mathrm{O}_{2}$. In the present study, for the expression of $\mathrm{SOD}$ activity during embryogenic competence acquisition, $\mathrm{CuSO}_{4} \cdot 5 \mathrm{H}_{2} \mathrm{O}$ at $7.5 \mu \mathrm{M}$ was efficient in promoting activity of the enzyme at higher levels with $6.83 \mu \mathrm{Kat} \mathrm{mg}^{-1}$ protein recorded during formation of the embryogenic tissue. It increased to 7.58 during embryos differentiation, 6.78 for proliferation and 5.13 in germinating embryos campared to the $5.38,5.98,5.45$ and $5.13 \mu \mathrm{Kat} \mathrm{mg}^{-1}$ protein of the control cultures, respectively. In the case of $\mathrm{AgNO}_{3}$ treatment, maximum activity of the enzyme was noted with $40 \mu \mathrm{M}$ treatment where 7.92 $\mu$ Kat $\mathrm{mg}^{-1}$ protein were recorded in embryogenic tissue. It increased further to 8.72 during embryos differentiation but, become reduced to 7.42 for proliferation and least during germination, having 6.33 (Fig. $3 \mathrm{~A}_{1-4}$ ). Combination of $\mathrm{AgNO}_{3}+\mathrm{CuSO}_{4} \cdot 5 \mathrm{H}_{2} \mathrm{O}$ amendment in the cultivation medium at different concentration levels promoted SE accompanied with SOD expression; the activity was high during embryogenic tissue formation with $8.55 \mu \mathrm{Kat} \mathrm{mg}^{-1}$ protein. It increased to 8.99 during somatic embryos induction, 7.93 during its proliferation and lowest during somatic embryos germination where $6.39 \mu \mathrm{Kat}$ $\mathrm{mg}^{-1}$ protein was recorded $\left(\mathrm{Fig} .3 \mathrm{~A}_{1-4}\right)$. This suggests the promotory role of the metals on SE to be 
associated with the expression of SODs at differential levels commensurate with stage of somatic embryos development through gradual reduction in expression levels of the enzyme.

Low intracellular levels of $\mathrm{H}_{2} \mathrm{O}_{2}$ could promote cell growth and its increased accumulation for $\mathrm{SE}$ through the role it plays as cellular messenger that induce gene expression essential for the SE (Cui et al. 1999). However, during later stages, excessive accumulation of $\mathrm{H}_{2} \mathrm{O}_{2}$, due to the low activity of CAT and other peroxidases may result into tissue browning and cell necrosis (Laukkannen et al. 1999; Kong et al. 2012; Nic-Can et al. 2015). Catalase is largely associated with the removal of high levels of $\mathrm{H}_{2} \mathrm{O}_{2}$ in cells (Klapheck et al. 1990) and reduction in its activity with low accumulation of $\mathrm{H}_{2} \mathrm{O}_{2}$ promotes SE (Cui et al. 1999). In $\mathrm{CuSO}_{4}$ treatment of the cultures, expression of CAT was highest with $7.5 \mu \mathrm{M}$ over other concentrations tested with $6.11 \mu \mathrm{Kat} \mathrm{mg}^{-1}$ protein recorded during embryogenic tissue formation. It decreased to 5.24 during somatic embryos induction, 4.72 for proliferating embryos and 3.21 in germinating somatic embryos compared to the 3.54 in the control of embryogenic tissue, 3.39 for somatic embryos induction, 2.98 for proliferation and $2.43 \mu \mathrm{Kat} \mathrm{mg}^{-1}$ protein of the germination (Fig. $3 \mathrm{~B}_{1-4}$ ). For $\mathrm{AgNO}_{3}$ treatment, highest CAT activity was noted with $40 \mu \mathrm{M}$ treatments where $6.99 \mu \mathrm{Kat}$ $\mathrm{mg}^{-1}$ protein was recorded in embryogenic tissue formation. It decreased to 6.97 during somatic embryos differentiation, 6.15 in proliferating embryos and $4.42 \mu \mathrm{Kat} \mathrm{mg}^{-1}$ protein during germination. Combination of the two metals at different concentrations promoted SE accompanied with decrease in CAT activity; activity of the enzyme was high during embryogenic tissue formation for which $7.76 \mu \mathrm{Kat}$ $\mathrm{mg}^{-1}$ protein was recorded. It showed further decrease with advancement in somatic embryos differentiation with 6.97 during embryos formation, 6.67 for proliferation and $4.69 \mu \mathrm{Kat} \mathrm{mg}^{-1}$ protein for the germination, suggesting gradual decrease in CAT expression during SE in G. hybridus influenced by $\mathrm{CuSO}_{4}, \mathrm{AgNO}_{3}$ and their combination treatment levels (Fig. 3B $\mathrm{B}_{1-4}$ ). Increase in activity of CAT was observed with up to $10 \mu \mathrm{M}$ treatment of Erythrina variegata in vitro cultures with $\mathrm{CuSO}_{4} \cdot 5 \mathrm{H}_{2} \mathrm{O}$, and its higher concentrations were insignificant while SOD expression was high in all the treatments tested, and showed dose-dependent trend in activity (Javed et al. 2017).

Ascorbate peroxidase, derived from ascorbic acid in cells, is involved in the reduction of $\mathrm{H}_{2} \mathrm{O}_{2}$ to water and at the same time oxidizes ascorbate to MDA. Activity of the enzyme was higher in $\mathrm{AgNO}_{3}$ treated cultures over that of the $\mathrm{CuSO}_{4} \cdot 5 \mathrm{H}_{2} \mathrm{O}$ : in the case of $\mathrm{AgNO}_{3}$ treated cultures, highest activity was noted in $40 \mu \mathrm{M}$ treatment with $4.62 \mu \mathrm{Kat} \mathrm{mg}^{-1}$ protein recorded during embryogenic tissue formation. It decreased to 4.29 during embryos differentiation, 3.94 for proliferation and $2.94 \mu \mathrm{Kat} \mathrm{mg}^{-1}$ protein during germination compared to the control of $2.74,2.23,1.85$ and $1.64 \mu \mathrm{Kat} \mathrm{mg}^{-1}$ protein, respectively. For $\mathrm{CuSO}_{4} \cdot 5 \mathrm{H}_{2} \mathrm{O}$, higher activity of the enzyme was observed in cultures treated with $7.5 \mu \mathrm{M}$ where $3.86 \mu \mathrm{Kat}$ $\mathrm{mg}^{-1}$ protein was recorded in embryogenic tissue. It decreased to 3.58 during embryos differentiation, 2.98 for proliferating embryos, and $2.17 \mu \mathrm{Kat} \mathrm{mg}^{-1}$ protein for germinating somatic embryos (Fig. $3 \mathrm{C}_{1-4}$ ). Combinatorial treatment of the various tissues with the two metals produced highest tissue mass differentiation and other responses accompanied with increased activity of the enzymes, suggesting their 
synergistic influence response. Combinatorial treatment of $\mathrm{AgNO}_{3} 40 \mu \mathrm{M}+\mathrm{CuSO}_{4} \cdot 5 \mathrm{H}_{2} \mathrm{O} 7.5 \mu \mathrm{M}$ gave maximum response and APX activity with $4.75 \mu \mathrm{Kat} \mathrm{mg}^{-1}$ protein recorded during embryogenic tissue formation that subsequently decreased to 4.28 in differentiating embryos. During proliferation of the somatic embryos, it decreased to 4.12 and then to $3.34 \mu \mathrm{Kat} \mathrm{mg}^{-1}$ protein in germinating embryos compared to the control cultures (Fig. 3C $\mathrm{C}_{1-4}$ ). Gupta and Datta (2004) reported changes in the activities of SOD, CAT and peroxidase during the first 14 days of SE in Gladiolus. According to their study, activities of SOD peaked during the period when somatic embryos as $\nabla$ tiny beads $\mathbb{Z}$ appeared but, become reduced with further development of the embryos, similar to results of our study in the control and metal treated cultures of the various embryo tissues analyzed but, variable on culture duration (Fig. $3 A-C$ ).

Guaiacol peroxidase that also plays role in cellular detoxification of $\mathrm{H}_{2} \mathrm{O}_{2}$ accumulated due to the activity of SOD to tolerable levels essential for morphogenesis, showed higher activity in $\mathrm{AgNO}_{3}$ treated cultures over the $\mathrm{CuSO}_{4} \cdot 5 \mathrm{H}_{2} \mathrm{O}$. However, combinatorial treatments were more efficient, suggesting their differential influence to morphogenesis at variable levels supplemented in culture medium (Fig. $3 \mathrm{D}_{1-4}$ ). In the case of $\mathrm{CuSO}_{4} \cdot 5 \mathrm{H}_{2} \mathrm{O}$ treatments, maximum of the activity was noted on medium supplemented with $7.5 \mu \mathrm{M}$ cultures where $2.41 \mu \mathrm{Kat} \mathrm{mg}^{-1}$ protein was recorded during embryogenic tissue formation. It decreased to 2.18 during somatic embryos differentiation, 2.14 for the proliferation and $1.59 \mu \mathrm{Kat} \mathrm{mg}^{-1}$ protein during mature embryos germination when compared to $1.85,1.57,1.46$ and $1.28 \mu \mathrm{Kat} \mathrm{mg}^{-1}$ protein of the respective control cultures (Fig. $3 \mathrm{D}_{1-4}$ ). In the case of $\mathrm{AgNO}_{3}$ treatments, $40 \mu \mathrm{M}$ proved the most efficient with the production of $2.93 \mu \mathrm{Kat} \mathrm{mg}^{-1}$ protein GPX activity during embryogenic tissue formation, 2.65 for somatic embryos differentiation while proliferating embryos had 2.59 and germinating embryos showed $2.24 \mu \mathrm{Kat} \mathrm{mg}{ }^{-1}$ protein after four weeks cultivation. Combined treatment of $\mathrm{AgNO}_{3} 40 \mu \mathrm{M}+\mathrm{CuSO}_{4} \cdot 5 \mathrm{H}_{2} \mathrm{O}$ $7.5 \mu \mathrm{M}$ produced maximum of $3.27 \mu \mathrm{Kat} \mathrm{mg}^{-1}$ protein GPX activity during embryogenic tissue formation, decreased to 2.97 during somatic embryos differentiation and further to 2.75 for somatic embryos proliferation while lowest was recorded in germinating somatic embryos with $2.52 \mu \mathrm{Kat} \mathrm{mg}^{-1}$ protein GPX activity, suggesting decreased expression of the enzyme during the various developmental stages to scavenge SOD-generated free radicals and other cellular toxic stress agents.

In vitro morphogenesis of $\mathrm{SE}$ is associated with high cellular stress that generates free radicals at higher levels in cells through the activity of SODs which may result in membrane damages (Zavattieri et al. 2010). Among parameters that can be used to study extent of membrane damage due to the cellular oxidative stress that causes lipid peroxidation by polyunsaturated fatty acids hydroperoxidation, is the activity of MDA in plant cells (Bailly et al. 1996). Excessive accumulation of $\mathrm{Cu}^{2+}$ in the growth medium may cause range of toxic effects that includes inhibition of photosynthetic rate that damages plasmamembrane permeability, and may result in metabolic disorder(s) due to Cu toxicity to plant species and varieties under cultivation (Gori et al. 1998; Macnair et al. 2000). In the present study, $\mathrm{CuSO}_{4} \cdot 5 \mathrm{H}_{2} \mathrm{O}, \mathrm{AgNO}_{3}$ and their combined treatments enhanced the activity of MDA at various stages of morphogenesis commensurate with the enhancement on tissue differentiation observed due to influence of the metals. However, the most efficient been combinatorial treatments over the singular metal

Page $14 / 33$ 
treatment (Fig. $3 \mathrm{E}_{1-4}$ ). For $\mathrm{CuSO}_{4} \cdot 5 \mathrm{H}_{2} \mathrm{O}, 7.5 \mu \mathrm{M}$ treatment was the most efficient where $15.49 \mu \mathrm{Kat} \mathrm{mg}^{-1}$ protein MDA activity was recored during embryogenic tissue formation. It decreased to 15.36 during somatic embryos differentiation, 14.59 for its proliferation while germinating embryos showed 11.15 $\mu \mathrm{Kat} \mathrm{mg}{ }^{-1}$ protein MDA activity. Treatment with $\mathrm{AgNO}_{3}$ levels gave the best results with $40 \mu \mathrm{M}$; maximum of $18.16 \mu \mathrm{Kat} \mathrm{mg}^{-1}$ protein MDA activity recorded during embryogenic tissue formation but, decreased to 17.85 during somatic embryos differentiation. This was further decreased during embryos proliferation with 17.48 MDA activity and 15.52 in germinating embryos compared to the control cultures where 9.78, $9.21,8.46$ and $8.24 \mu \mathrm{Kat} \mathrm{mg}^{-1}$ protein MDA activity was respectively recorded. To further asses the possible synergistic effect of the two metals on promoting the morphogenic process and possible involvement of MDA activity, the assay was carriedout after cultures were treated with $\mathrm{AgNO}_{3}+$ $\mathrm{CuSO}_{4} \cdot 5 \mathrm{H}_{2} \mathrm{O}$ combination for four weeks. High activity of the enzyme was observed during embryogenic tissue formation where $19.36 \mu \mathrm{Kat} \mathrm{mg}^{-1}$ protein was recorded. This was decreased to 18.91 during somatic embryos differentiation, then to 18.21 in proliferating embryos while germinating embryos had $16.95 \mu \mathrm{Kat} \mathrm{mg}^{-1}$ protein MDA activity, suggesting possible high membrane damage imposed to tissues during SE due to high cellular levels of hydroxy, alkoxy and peroxy radicals accumulation that trigger activity of the enzyme to overcome membrane damage at various stages of morphogenesis that high expression of SOD, CAT, APX and GPX could not ameliorate (Fig. 3E $\mathrm{E}_{1-4}$ ). It can also be ascribed to inability of peroxidases activity in catalyzing $\mathrm{H}_{2} \mathrm{O}_{2}$ detoxification that resulted in production of high cellular levels of toxic hydroxyl radicals from $\mathrm{H}_{2} \mathrm{O}_{2}$ due to the production of superoxide radicals (Chen and Schopfer 1999; Piqueras et al. 2002). Lower espression of peroxidase, polyphenol oxidase and indole-3-acetic acid (IAA) oxidase activities had been observed in plants that showed Cu deficiency but, supplemented with the metal in nutrients cultivation medium (Marschner 1995).

\section{Changes during shoot morphogenesis}

To study the influence of $\mathrm{CuSO}_{4} \cdot 5 \mathrm{H}_{2} \mathrm{O}, \mathrm{AgNO}_{3}$ and their combinations on shoot morphogenesisassociated biochemical changes in G. hybridus, different concentration of the two metals were tested and parameters of $\mathrm{Chl}$, Cars, glycinebetaine and proline content evaluated from harvested shoot cultures (Fig. 3F-G). Exposure to high concentration of the metals may inhibit electron transport chain by blocking photosynthetic electron transport in PS II oxidizing or reducing sites of the photosystem, which may result in ROS generation and oxidative stress to plants (Fernandes and Henrique 1991; Dudev and Lim 2008; Huang et al. 2020; Pontes et al. 2020) with overall effect on plant physiological parameters associated with photosynthetic quantum and other adjustment responses in metabolic processes (Souza et al. 2019; Hameed et al. 2021). In the present study, Chla content of the shoot cultures was highest in $7.5 \mu \mathrm{M}$ treatment with $\mathrm{CuSO}_{4} .5 \mathrm{H}_{2} \mathrm{O}$ where $0.1981 \pm 0.12 \mathrm{mg} \mathrm{g}^{-1} \mathrm{FW}$ were accumulated over the control and other concentrations tested. For $\mathrm{AgNO}_{3}$ treatment of the cultures, maximum production of the pigment molecule was recorded in $40 \mu \mathrm{M}$ treatment with $0.29 \pm 0.11 \mathrm{mg} \mathrm{g}^{-1} \mathrm{FW}$ Chla. Combination of the two metals at varied concentration levels yield highest production of $0.32 \pm 0.14 \mathrm{mg} \mathrm{g}^{-1} \mathrm{FW}$ Chla in $\mathrm{AgNO}_{3} 40 \mu \mathrm{M}+\mathrm{CuSO}_{4} \cdot 5 \mathrm{H}_{2} \mathrm{O} 7.5 \mu \mathrm{M}$ treatment (Fig. $3 \mathrm{~F}_{1}$ ). In the case of Chlb, maximum of $1.18 \pm 0.13$ 
$\mathrm{mg} \mathrm{g}^{-1} \mathrm{FW}$ was recorded in $7.5 \mu \mathrm{M} \mathrm{CuSO}_{4} .5 \mathrm{H}_{2} \mathrm{O}$ treatment over other concentrations tested while $\mathrm{AgNO}_{3}$ at $40 \mu \mathrm{M}$ proved more effective with the production of $1.34 \pm 0.12 \mathrm{mg} \mathrm{g}^{-1} \mathrm{FW}$ Chlb $\left(\mathrm{Fig} .3 \mathrm{~F}_{2}\right)$. Combined treatment assessment yield maximum of $1.42 \pm 0.10$ in $40 \mu \mathrm{M} \mathrm{AgNO}_{3}+7.5 \mu \mathrm{M} \mathrm{CuSO}_{4} \cdot 5 \mathrm{H}_{2} \mathrm{O}$ levels, suggesting the concentration as the most effective in promoting $\mathrm{Chl}$ biosynthesis essential for plant growth. For total $\mathrm{Chl}$ content of the shoot cultures, maximum was recorded in $7.5 \mu \mathrm{M} \mathrm{CuSO}_{4} \cdot 5 \mathrm{H}_{2} \mathrm{O}$ treatments where $1.192 \pm 0.12 \mathrm{mg} \mathrm{g}^{-1} \mathrm{FW} \mathrm{Chl}$ was recorded compared to the higher of $1.34 \pm 0.13$ achieved with $40 \mu \mathrm{M} \mathrm{AgNO}_{3}$ treatment of the shoot cultures and over other treatments tested (Fig. $\left.3 \mathrm{~F}_{3}\right)$. Combination treatments of the two metals further enhanced total Chl accumulation to $1.52 \pm 0.11 \mathrm{mg} \mathrm{g}^{-1}$ FW recorded with $\mathrm{AgNO}_{3} 40 \mu \mathrm{M}+\mathrm{CuSO}_{4} \cdot 5 \mathrm{H}_{2} \mathrm{O} 7.5 \mu \mathrm{M}$ combination levels. In the case of Cars production, $\mathrm{CuSO}_{4} \cdot 5 \mathrm{H}_{2} \mathrm{O}$ at $7.5 \mu \mathrm{M}$ was equally more efficient in their accumulation with $0.616 \pm 0.12 \mathrm{mg} \mathrm{g}^{-1} \mathrm{FW}$ recorded in the treatment over other amended concentration levels of the metal. $\mathrm{AgNO}_{3}$ at $40 \mu \mathrm{M}$ proved more efficient in Cars production enhancement in the shoot cultures with the production of $0.73 \pm 0.17$ $\mathrm{mg} \mathrm{g}^{-1} \mathrm{FW}$ while combination treatment with the two metals yield maximum accumulation with $\mathrm{AgNO}_{3}$ $40 \mu \mathrm{M}+\mathrm{CuSO}_{4} \cdot 5 \mathrm{H}_{2} \mathrm{O} 7.5 \mu \mathrm{M}$ levels, with the production of $0.743 \pm 0.14 \mathrm{mg} \mathrm{g}^{-1} \mathrm{FW}$ over other combination treatments tested $\left(\mathrm{Fig} .3 \mathrm{~F}_{4}\right)$. This suggests that supplementing $\mathrm{Cu}$ in the culture medium at moderate levels enhanced leaves $\mathrm{Chl}$ content, while higher inhibited its biosynthesis due to possible effect on photosynthetic machinery of thyllakoids where it forms an integral functional unit of PS II (Hameed et al. 2021). Maximum shoot morphogenesis, elongation, leaves expansion and Chl content was achieved with shoot tip explants of Musa acuminata when cultivated on medium supplemented with $\mathrm{AgNO}_{3}$ (up to $10 \mathrm{mg} \mathrm{L}^{-1}$ ) over control cultures and other ethylene inhibitors tested (Tamimi 2015). Inhibition of ethylene action due to supplementation of $\mathrm{AgNO}_{3}$ in growth medium to serve as source of silver ions have promoted increase in leaves Chl content (Perl et al. 1988; Ehsanpour and Jones 2001). In Solanum tuberosum shoot cultures, treatment with $\mathrm{AgNO}_{3}$ up to $10 \mu \mathrm{M}$ promoted shoot morphogenesis Chla, Chlb and total Chl content of leaves while higher levels (above $15 \mu \mathrm{M}$ ) decreased the morphogenic response and total Chl content of leaves (Kaur and Kumar 2020). In Nicotiana tabacum control and Cutolerant tissue cultures, Chla and Chlb concentration showed no significant variation in accumulation but, the ratio of $\mathrm{Chla/Chlb}$ varied, suggesting its tolerance to the concentrations tested through proper chloroplast development (Gori et al. 1998). At high $\mathrm{CuSO}_{4}$ amendment in MS medium, improved shoot morphogenesis was achieved in Stevia rebaudina in vitro cultures and was associated with increase in $\mathrm{Chl}$ content but, higher levels proved detrimental to the cultures (Jain et al. 2009). Treatment of banana shoot cultures with $\mathrm{CuSO}_{4} \cdot 5 \mathrm{H}_{2} \mathrm{O}$ promoted high $\mathrm{Chl}$ accumulation in leaves with the highest been on medium added with $6.0 \mathrm{mg} \mathrm{L}^{-1}$ (Tamimi and Othman 2020). In E. variegata, moderate levels of copper $(10 \mu \mathrm{M})$ promoted shoot morphogenesis through the number of shoots induced per explant and their length while higher concentrations $(15-20 \mu \mathrm{M})$ proved toxic to the parameters, with leaves yellowing prevalent in cultures and changes in antioxidant systems (Javed et al. 2017), possibly due to essential role that Cu play as micronutrient needed for physiological metabolic enzyme processes of photosynthesis, respiration and hormones perception (Hansch and Mendel 2009; Nomura et al. 2015; Rahmati Ishka and Vatamaniuk 2020). 
Proline, an osmoprotectant that serve as storage sink of carbon, nitrogen and free radical scavenger, showed highest accumulation in $7.5 \mu \mathrm{M} \mathrm{CuSO}_{4} .5 \mathrm{H}_{2} \mathrm{O}$ medium treatment cultures, with the production of $158 \pm 0.19 \mu \mathrm{M} \mathrm{mg}^{-1} \mathrm{FW}$ over the maximum of $227 \pm 0.15$ in $\mathrm{AgNO}_{3}$ treatment of $40 \mu \mathrm{M}$ and other concentrations tested. Combination of the two metal salts further enhanced proline accumulation in the shoot cultures with the highest production been on $\mathrm{AgNO}_{3} 40 \mu \mathrm{M}+\mathrm{CuSO}_{4} .5 \mathrm{H}_{2} \mathrm{O} 7.5 \mu \mathrm{M}$ treatment cultures where $239 \pm 0.16 \mu \mathrm{M} \mathrm{mg}^{-1} \mathrm{FW}$ was recorded over other treatments tested (Fig. $3 \mathrm{G}_{1}$ ). Glycinebetaine production in the shoot cultures was enhanced by the $\mathrm{CuSO}_{4} \cdot 5 \mathrm{H}_{2} \mathrm{O}$ treatments with its highest accumulation achieved on medium supplemented with $7.5 \mu \mathrm{M}$ where $178 \pm 0.21 \mu \mathrm{M} \mathrm{mg}^{-1} \mathrm{FW}$ production over other concentrations tested. $\mathrm{AgNO}_{3}$ proved more effective in promoting the accumulation over $\mathrm{CuSO}_{4} \cdot 5 \mathrm{H}_{2} \mathrm{O}$ treatments, with the maximum production been on medium added with $40 \mu \mathrm{M}$ where $209 \pm 0.18 \mu \mathrm{M} \mathrm{mg}^{-1} \mathrm{FW}$ was accumulated by the shoots while combined treatment with the two metals resulted in highest production of $224 \pm 0.17 \mu \mathrm{M} \mathrm{mg}^{-1} \mathrm{FW}$ in $\mathrm{AgNO}_{3} 40 \mu \mathrm{M}+\mathrm{CuSO}_{4} \cdot 5 \mathrm{H}_{2} \mathrm{O} 7.5 \mu \mathrm{M}$ treatment level of the cultures and over other levels tested (Fig. $3 \mathrm{G}_{2}$ ). Reduction in the morphogenic response observed with higher levels of the metals in the present study can be explained by the possible triggering effect they had on Fenton reaction that generates hydroxyl radicals which are known to cause

lipid peroxidation, DNA and protein damage (Drazkiewicz et al. 2004). In a study with $\mathrm{AgNO}_{3}, \mathrm{CuSO}_{4}$ and their nanoparticles, Malik et al. (2021) reported their differential promotory influence on callus induction, embryogenic tissue formation and plant regeneration in Triticum aestivum genotypes in concentrationdependent manner, with the synthesized nanoparticles been more efficient over use of the two metals employed.

\section{Conclusion}

Results of the present study suggests that supplementing $\mathrm{CuSO}_{4}\left(5 \mathrm{H}_{2} \mathrm{O}\right), \mathrm{AgNO}_{3}$ or their combination in the in vitro growth medium of $G$. hybridus have promotory influence on callus induction, embryogenic tissue differentiation, SE, shoot morphogenesis and multiplication in concentration dependent manner. Supplementing the metals to in vitro growth medium influences tissue growth during the various morphogenic stages through influence on the physiological biochemical changes essential for the morphogenic processes. This can be ascribed to the role they play in influencing different physiological biochemical pathways and changes essential for the in vitro developmental processes.

\section{Abbreviations}

Plant Cell Tissue and Organ Culture PCTOC

Murashige and Skoog medium

MS

Plant growth regulators

PGRs

2,4-Dichlorophenoxy acetic acid 
2,4-D

$\mathrm{N}^{6}$-Benzylaminopurine

BAP

Naphthalene acetic acid

NAA

Indole butyric acid

IBA

Copper sulphate (hydrate)

$\mathrm{CuSO}_{4}$

Silver nitrate

$\mathrm{AgNO}_{3}$

Somatic embryogenesis

SE

Chlorophyll

$\mathrm{Chl}$

Photosystems

PS

Fresh weight

FW

Dried weight

DW

Reactive oxygen species

ROS

Superoxide dismutase

SOD

Hydrogen peroxide

$\mathrm{H}_{2} \mathrm{O}_{2}$

Catalase

CAT

Ascorbate peroxidase

APX

Guaiacol peroxidase

GPX

Malondialdehyde

MDA

Complete randomized block design

CRBD

\section{Declarations}




\section{Conflict of interest statement}

Authors declare that conflict of interest does not exist in the manuscript contents.

\section{Ethics approval and consent to participate}

The research work was carriedout in compliance with ethical standard that did not involve the use of humans.

\section{Consent for publication}

Authors declare having consent to publish the manuscript contents.

\section{Availability of data and material}

Available on reasonable request to corresponding author.

\section{Competing interests}

None exist

\section{Funding}

Not applicable

\section{Acknowledgement}

Authors are grateful to Department of Botany, Hamdard University New Delhi, India for providing research facilities.

\section{Authors' contributions}

TI conceived the research idea, performed all in vitro culture experiments but physiological and biochemical changes analysis experiment together with $\mathbf{Q}$, while $\mathbf{T I}, \mathbf{Q}$ and $\mathbf{S U}$ wrote, edited and approved the manuscript contents.

\section{References}

Abdolvand B, Zarghami R, Salari A (2018) The effects of $\mathrm{AgNO}_{3}$ and 2ip ( $\mathrm{N}^{6}$-(2-isopentenyl) adenine) on different stages of somatic embryogenesis in date palm (Phoenix dactylifera I.) (cv. medjool). Pak J Bot 50(2):495-502.

Alam N, Anis M (2019) Influence of silver nitrate in enhancing the in vitro shoot regeneration in Mucuna pruriens (L.) DC. - a multipurpose medicinal legume. Res J Life Sci Bioinform Pharmaceutic Chem Sci 5(2):476. doi:10.26479/2019.0502.34 
Alexieva V, Sergiev I, Mapelli S, Karanov E (2001) The effect of drought and ultraviolet radiation on growth and stress markers in pea and wheat. Plant Cell Environ 24(12):1337-1344. doi:10.1046/j.13653040.2001.00778.x

Al Ramadan R, Karas M, Ranusova P, Moravcikova J (2021) Effect of silver nitrate on in vitro regeneration and antioxidant responses of oilseed rape cultivars (Brassica napus L.). J Microbiol Biotechnol Food Sci 10(6):e4494. doi:10.15414/jmbfs.4494

Anantasaran J, Kanchanapoom K (2008) Influence of medium formula and silver nitrate on in vitro plant regeneration of Zinnia cultivars. Songklanakarin J Sci Technol 30(1):1-6.

Arnon DI (1949) Copper enzymes in isolated chloroplasts. Polyphenoloxidase in Beta vulgaris. Plant Physiol 24(1):1. doi:10.1104/pp.24.1.1

Arnon DI, Stout PR (1939) The essentiality of certain elements in minute quantity for plants with special reference to copper. Plant Physiol 14(2):371-375. doi:10.1104/pp.14.2.371

Arora A, Sairam RK, Srivastava GC (2002) Oxidative stress and antioxidative system in plants. Curr Sci $82: 1227-1238$.

Asada K, Kanematsu S, Uchida K (1977) Superoxide dismutases in photosynthetic organisms. Arch Biochem Biophys 74:551-564. doi:10.1007/978-1-4684-3270-1_46

Bais HP, Sudha GS, Ravishankar GA (2000) Putrescine and $\mathrm{AgNO}_{3}$ influences shoot multiplication, in vitro flowering and endogenous titres of polyamines in Chichorium intybus L cv Lucknow Local. J Plant Growth Regul 19(2):238-248. doi:10.1007/s003440000012

Bais HP, Sudha GS, Ravishankar GA (2001) Influence of putrescine $\mathrm{AgNO}_{3}$ and polyamine inhibitors on the morphogenetic response in untransformed and transformed tissues of Chichorium intybus and their regenerants. Plant Cell Rep 20(6):547-555. doi:10.1007/s002990100367

Baker AJM, Walker PL (1990) Eco-physiology of metal uptake by tolerant plants. In: Shaw AJ (ed) Heavy metal tolerance in plants: evolutionary aspects. CRC Press, Boca Raton, FL, pp 155-177.

Baszynski T, Król M, Krupa Z, Ruszkowska M, Wojcieska U, Wolinska D (1982) Photosynthetic apparatus of spinach exposed to excess copper. Z. Pflanzenphysiol 108(5):385-395. doi:10.1016/S0044328X(82)80163-3

Bates LS, Waldren RP, Teare ID (1973) Rapid determination of free proline for water-stress studies. Plant Soil 39(1):205-207. doi:10.1007/BF00018060

Becana M, Moran JF, Iturbe-Ormaetxe I (1986) Iron-dependent oxygen free radical generation in plants subjected to environmental stress: toxicity and antioxidant protection. Plant Soil 201(1):137-147. doi:10.1023/A:1004375732137 
Beyer EM (1976a) A potent inhibitor of ethylene action in plants. Plant Physiol 58(3):268-271. doi:10.1104/pp.58.3.268.

Beyer EM (1976b) Silver ion: a potent anti-ethylene agent in cucumber and tomato. HortSci 11(3):175196.

Bidabadi SS, Jain SM (2020) Cellular, molecular, and physiological aspects of in vitro plant regeneration. Plants 9(6):702. doi:10.3390/plants9060702

Burkhead JL, Reynolds KAG, Abdel-Ghany SE, Cohu CM, Pilon M (2009) Copper homeostasis. New Phytol 182(4):799-816. doi:10.1111/j.1469-8137.2009.02846.x.

Cakmak I, Marschner H (1992) Magnesium deficiency and high light intensity enhance activities of superoxide dismutase, ascorbate peroxidase, and glutathione reductase in bean leaves. Plant Physiol 98(4):1222-1227. doi:0032-0889/92/98/1 222/06/\$01

Caldas LS, Haridasan P, Ferreira ME (1990) Meios nutritivos. In: Torres AC, Caldas LS (Eds) Técnicas e Aplicações da Cultura de Tecidos de Plantas (pp 37-70). ABCTP/EMBRAPA-CNPH, Brasília.

Cardoso JC (2019) Silver nitrate enhances in vitro development and quality of shoots of Anthurium andraeanum. Scientia Hortic 253(27):358-363. doi:10.1016/j.scienta.2019.04.054

Chen SX, Schopfer P (1999) Hydroxyl-radical production in physiological reactions. A novel function of peroxidase. Eur J Biochem 260(3):726-735. doi:10.1046/j.1432-1327.1999.00199.x.

Ciardi J, Klee H (2001) Regulation of ethylene mediated responses at the level of the receptor. Ann Bot 88(5):813-822. doi:10.1006/anbo.2001.1523

Cristea TO, Leonte C, Brezeanu C, Brezeanu M, Ambarus S, Calin M, Prisecaru M (2012) Effect of $\mathrm{AgNO}_{3}$ on androgenesis of Brassica oleracea L. anthers cultivated in vitro. Afri J Biotechnol 11(73):1378813795. doi:10.5897/AJB12.2157

Dahleen LS (1995) Improved plant regeneration from barley callus cultures by increased copper levels. Plant Cell Tiss Organ Cult 43:267-269. doi:10.1007/BF00039954

Dahleen LS, Bregitzer P (2002) An improved media system for higher regeneration rates from barley immature embryo derived callus cultures of commercial cultivars. Crop Sci 42(3):934938. doi:10.2135/cropsci2002.9340

Dalton SJ (2020) A reformulation of Murashige and Skoog medium (WPBS medium) improves embryogenesis, morphogenesis and transformation efficiency in temperate and tropical grasses and cereals. Plant Cell Tiss Organ Cult 141:257-273. doi:10.1007/s11240-020-01784-8 
de Almeida M, Graner ÉM, Brondani GE, de Oliveira LS, Artioli FA, de Almeida LV, Leone GF, Baccarin FJB, de Oliveira Antonelli P, Cordeiro GM, Oberschelp GPJ (2015) Plant morphogenesis: theorical bases. Adv For Sci 2(1):13-22.

DeFossard RA (1974) Responses of the callus from zygotal and microsporal tobacco (Nicotiana tabacum L.) to various combinations of iodole acetic acid and kinetine. New Phytol 77(4):699. doi:10.1111/j.14698137.1974.tb01298.x

Delhaize E, Loneragan JF, Webb J (1985) Development of three copper metalloenzyme in clover leaves. Plant Physiol 78(1):4-7. doi:10.1104/pp.78.1.4.

Diab MI (2017) In vitro propagation of the endangered date palm (Phoenix dactylifera L.) cv. Ghazal: 2Improvement of germination and development of embryos by silver nitrate and silver thiosulfate. IOSR J Biotechnol Biochem 3(4):66-74. doi:10.9790/264X-03046674

Drazkiewicz M, Skórzynska-Polit E, Krupa Z (2004) Copper-induced oxidative stress and antioxidant defence in Arabidopsis thaliana. BioMetals 17(4):379-387. doi:10.1023/b:biom.0000029417.18154.22

Droppa M, Horvath G (1990) The role of copper in photosynthesis-critical review. Plant Sci 9(2):111123. doi:10.1080/07352689009382284

Dudev T, Lim C (2008) Metal binding affinity and selectivity in metalloproteins: insights from computational studies. Annu Rev Biophys 37:97-116. doi:10.1146/annurev.biophys.37.032807.125811

Dunn GM, Huth JR, Lewty MJ (1997) Coating nursery containers with copper carbonate improves root morphology of five native Australian tree species used in agroforestry systems. Agrofor Systems 37:143155. doi:10.1023/A:1005863707277

Dwivedi P, Amin D, Sharma A (2020) Effect of differential concentration of micronutrient copper and zinc on in vitro morphogenesis of Foeniculum vulgare Mill. Plant Physiol Rep doi:10.1007/s40502-019-004784

Ehsanpour AA, Jones MGK (2001) Plant regeneration from mesophyll protoplasts of potato (Solanum tuberosum L.) cultivar Delaware using silver thiosulfate (STS). J Sci Islamic Repub Iran 12(2):103-110.

Faria GA, Felizardo LM, Ferreira AFA, Rocha PS, Suzuki AN, Souza AS, Junghans TG, Costa MAPC, Peixoto APB, Morais AR, Lopes BG, Oliveira TA (2017) Concentrations of silver nitrate in the in vitro development and conservation of Passiflora gibertii N. E. Brown. American J Plant Sci 8(12):2944-2955. doi:10.4236/ajps.2017.812199

Fernandes JC, Henriques FS (1991) Biochemical, physiological, and structural efects of excess copper in plants. Bot Rev 57(3):246-273. doi:10.1007/BF02858564 
Fuentes S, Calheiros M, Manetti-Filho J, Vieira L (2000) The effects of silver nitrate and different carbohydrate sources on somatic embryogenesis in Coffea canephora. Plant Cell Tiss Organ Cult 60(1):5-13. doi:10.1023/A:1006474324652

Garcia C, Furtado de Almeida AA, Costa M, Britto D, Valle R, Royaert S, Marelli JP (2019) Abnormalities in somatic embryogenesis caused by 2,4-D: an overview. Plant Cell Tiss Organ Cult 137:193-212. doi:10.1007/s11240-019-01569-8

Ghobeishavi H, Uliaie ED, Alavikia SS, Valizadeh M (2015) Study of factors influencing somatic embryogenesis in Rice (Oryza sativa L.). Intl J Adv Biol Biom Res 3(1):43-50.

Giridhar P, Indu EP, Ramu D, Ravishankar GA (2003) Effect of silver nitrate on in vitro shoot growth of coffee. Trop Sci 43(3):144-146. doi:10.1002/ts.106

Giridhar P, Indu EP, Vinod K, Chandrashekar A, Ravishankar GA (2004) Direct somatic embryogenesis from Coffea arabica L. and Coffea canephora P ex Fr. under the influence of ethylene action inhibitor-silver nitrate. Acta Physiol Plant 26(3):299-305. doi:10.1007/s11738-004-0020-0

Good R (1931) A theory of plant geography. New Phytol 30(3):139-171. doi:10.1111/j.14698137.1931.tb07414.x

Gori P, Schiff S, Santandrea G, Bannici A (1998) Response of in vitro cultures of Nicotiana tabacum L. to copper stress and selection of plants from Cu-tolerant callus. Plant Cell Tiss Organ Cult 53(3):161-169. doi:10.1023/A:1006048031956

Gressel J, Galun E (1994) Causes of photooxidative stress and amelioration of defence systems in plants. In: Foyer CH, Mullineaux PM (Eds), CRC Press Boca Raton FL, Pp.237-327.

doi:10.1201/9781351070454

Grieve CM, Grattan SR (1983) Rapid assay for the determination of water soluble quaternary ammonium compounds. Plant Soil 70(2):303-307. doi:10.1007/BF02374789

Halliwell B, Gutteridge JM (1984) Oxygen toxicity, oxygen radicals, transition metals and disease. Biochem J 219(1):1-14. doi:10.1042/bj2190001

Hameed A, Ahmed MZ, Hussain T, Aziz I, Ahmad N, Gul B, Nielsen BL (2021) Effects of salinity stress on chloroplast structure and function. Cells 10(8):2023. doi:10.3390/cells10082023

Hansch R, Mendel RR (2009) Physiological functions of mineral micronutrients ( $\mathrm{Cu}, \mathrm{Zn}, \mathrm{Mn}, \mathrm{Fe}, \mathrm{Ni}, \mathrm{Mo}, \mathrm{B}$, Cl). Curr Opin Plant Biol 12(3):259-266. doi:10.1016/j.pbi.2009.05.006

Hemeda HM, Klein BP (1990) Effects of naturally occurring antioxidants on peroxidase activity of vegetable extracts. J Food Sci 55(1):184-185. doi:10.1111/j.1365-2621.1990.tb06048.x 
Huang WL, Wu FL, Huang HY, Huang WT, Deng CL, Yang LT, Huang ZR, Chen LS (2020) Excess copperinduced alterations of protein profiles and related physiological parameters in citrus leaves. Plants 9(3):291. doi:10.3390/plants9030291

Hyde CL, Phillips GC (1996) Silver nitrate promotes shoot development and plant regeneration of chile pepper (Capsicum annuum L.) via organogenesis. In Vitro Cell Dev Biol - Plant 32:72-80.

Ibrahim AS, Fahmy AH, Ahmed SS (2018) Copper nanoparticles elevate regeneration capacity of (Ocimum basilicum L.) plant via somatic embryogenesis. Plant Cell Tiss Organ Cult 136:41-50. doi:10.1007/s11240-018-1489-3

Isah T (2019) Changes in the biochemical parameters of albino, hyperhydric and normal green leaves of Caladium bicolor cv. "Bleeding hearts" in vitro long-term cultures. J Photochem Photobiol B: Biol 191:88-98. doi:10.1016/j.jphotobiol.2018.12.01

Isah T, Umar S (2018) Influencing in vitro clonal propagation ofChonemorpha fragrans (moon) Alston by culture media strength, plant growth regulators, carbon source and photoperiodic incubation. J For Res 31(9):27-43. doi:10.1007/s11676-018-0794-3

Jain P, Kachhwaha S, Kothari SL (2009) Improved micropropagation protocol and enhancement in biomass and chlorophyll content in Stevia rebaudiana (Bert.) Bertoni by using high copper levels in the culture medium. Sci Hortic 119(3):315-319. doi:10.1016/j.scienta.2008.08.015

Javed SB, Alatar AA, Riyadh Basahi R, Anis M, Faisal M, Husain FM (2017) Copper induced suppression of systemic microbial contamination in Erythrina variegata $\mathrm{L}$. during in vitro culture. Plant Cell Tiss Organ Cult 128(2):249-258. doi:10.1007/s11240-016-1104-4

Joshi A, Kothari SL (2007) High copper levels in the medium improves shoot bud differentiation and elongation from the cultured cotyledons of Capsicum annuum L. Plant Cell Tiss Organ Cult 88(2):127133. doi:10.1007/s11240-006-9171-6

Kairong C, Xing G, Liu X, Xing G, Wang Y (1999) Effect of hydrogen peroxide on somatic embryogenesis of Lycium barbarum L. Plant Sci 146:9-16.

Kaur A, Kumar A (2020) The effect of gelling agent, medium pH and silver nitrate on adventitious shoot regeneration in Solanum tuberosum. doi:10.1101/2020.01.03.894063

Khajuria AK, Hano C, Bisht NS (2021) Somatic embryogenesis and plant regeneration in Viola canescens Wall. Ex. Roxb.: an endangered Himalayan herb. Plants 10(4):761. doi:10.3390/plants10040761

Kim DH, Gopal J, Sivanesan I (2017) Nanomaterials in plant tissue culture: the disclosed and undisclosed. RSC Adv 7:36492-36505. doi:10.1039/c7ra07025jrsc.li/rsc-advances 
Kong DM, Shen $\mathrm{HL}$, $\mathrm{Li} \mathrm{N}(2012)$ Influence of $\mathrm{AgNO}_{3}$ on somatic embryo induction and development in Manchurian ash (Fraxinus mandshurica Rupr.). Afri J Biotechnol 11(1):120-125. doi:10.5897/AJB11.3061

Kong L, Yeung EC (1995) Effect of silver nitrate and polyethylene glycol on white spruce (Picea glauca) somatic embryo development: enhancing cotyledonary embryo formation and endogenous ABA content. Physiol Plant 93(2):298-304.doi:10.1111/j.1399-3054.1995.tb02232.x

Kothari SL, Agrawal K, Kumar S (2004) Inorganic nutrient manipulation for highly improved in vitro plant regeneration in finger millet [Eleusine coracana (L.) Gaertn.]. In Vitro Cell Dev Biol - Plant 40(5):515519. doi:10.1079/IVP2004564

Kothari-Chajer A, Sharma M, Kachhwaha S, Kothari SL (2008) Micronutrient optimization results into highly improved in vitro plant regeneration in kodo (Paspalum scrobiculatum L.) and finger (Eleusine coracana (L.) Gaertn.) millets. Plant Cell Tiss Organ Cult 94(2):105-112. doi:10.1007/s11240-008-9392-y

Kumar V, Parvatam G, Ravishankar GA (2009a) $\mathrm{AgNO}_{3}$ - a potential regulator of ethylene activity and plant growth modulator. Electronic J Biotechnol 12(2):1-15. doi:10.2225/vol12-issue2-fulltext-1

Kumar R, Mehrotra NK, Nautiyal BD, Kumar P, Singh PK (2009b) Effect of copper on growth, yield and concentration of $\mathrm{Fe}, \mathrm{Mn}, \mathrm{Zn}$ and $\mathrm{Cu}$ in wheat plants (Triticum aestivum $\mathrm{L}$.). J Environ Biol 30(4):485-488.

Kumar V, Ramakrishna A, Ravishankar GA (2007) Influence of different ethylene inhibitors on somatic embryogenesis and secondary embryogenesis from Coffea canephora P ex Fr. In Vitro Cell Dev Biol Plant 43(6):602-607. doi:10.1007/s11627-007-9067-0

Lamb C, Dixon RA (1997) The oxidative burst in plant disease resistance. Annu Rev Plant Physiol Plant Mol Biol 48:251-275. doi:10.1146/annurev.arplant.48.1.251

Lambardi M, Sharma KK, Thorpe TA (1993) Optimization of in vitro bud induction and plantlet formation from mature embryos of Aleppo pine (Pinus halepensis Mill.). In Vitro Cell Dev Biol 29:189-199.

Laukkannen AL, Haggmen H, Kontunen-Soppela S, Hohtola A (1999) Tissue browning of in vitro culture of Scots pine: role of peroxidase and polyphenol oxidase. Physiol Plant 106(3):337343. doi:10.1034/j.1399-3054.1999.106312.x

Lequeux H, Hermans C, Lutts S, Verbruggen N (2010) Response to copper excess in Arabidopsis thaliana: impact on the root system architecture, hormone distribution, lignin accumulation and mineral profile. Plant Physiol Biochem 48(8):673-682. doi:10.1016/j.plaphy.2010.05.005

Lipman CB, Mackinney G (1931) Proof of the essential nature of copper for higher green plants. Plant Physiol 6(3):593-599. doi:10.1104/pp.6.3.593 
Lokhande VH, Nikam TD, Penna S (2010) Biochemical, physiological and growth changes in response to salinity in callus cultures of Sesuvium portulacastrum L. Plant Cell Tiss Organ Cult 102(1):1725. doi:10.1007/s11240-010-9699-3

Lombardi L, Sebastiani L (2005) Copper toxicity in Prunus cerasifera: growth and antioxidant enzyme responses of in vitro grown plants. Plant Sci 168(3):797-802. doi:10.1016/j.plantsci.2004.10.012

López-Gómez PT, Iracheta-Donjuan L, Ojeda-Zacarías MDC, Ducos JP (2016) Culture medium and inhibitors of ethylene in the coffee somatic embryogenesis. Revist Mexican de Ciencias Agríc 7(7):17491757.

Macnair MR, Tilstone GH, Smith SE (2000) The genetics of metal tolerance and accumulation in higher plants. In: Terry N, Banuelos G (Eds.), Phytoremediation of contaminated soil and water, pp 235-250. CRC Press LLC.

Mahendra VSSP, Dutta Gupta S (2004) Trichromatic sorting of in vitro regenerated plants of Gladiolus using adaptive resonance theory. Curr Sci 87(3):10.

Maksymiec W (1997) Effect of copper on cellular processes in higher plants. Photosynthetic 34(3):321342. doi:10.1023/A:1006818815528

Malik WA, Mahmood I, Abdul Razzaq, Afzal M, Shah GA, Iqbal A, Zain M, Ditta A, Asad SA, Ahmad I, Mangi N, Ye W (2021) Exploring potential of copper and silver nano particles to establish efficient callogenesis and regeneration system for wheat (Triticum aestivum L.). GM Crops Food 1-22. doi:10.1080/21645698.2021.1917975

Memon N (2012) In vitro propagation of Gladiolus plantlets and cormels. J Hort Sci Orn Plants 4(3):280291. doi:10.5829/idosi.jhsop.2012.4.3.258

Memon N, Yasmin A, Pahoja VM, Hussain Z, Ahmad I (2012) In vitro regeneration of gladiolus propagules. J Agricult Technol 8(7):2331-2351.

Memon NUN, Wahocho NA, Miano TF, Leghari MH (2016) Propagation of Gladiolus corms and cormels: a review. African J Biotechnol 15(32):1699-1710. doi:10.5897/AJB2012.1396

Mookkan $\mathrm{M}$, Andy $\mathrm{G}$ (2014) $\mathrm{AgNO}_{3}$ boosted high-frequency shoot regeneration in Vigna mungo (L.) Hepper. Plant Signal Behav 9(10):e972284. doi:10.4161/psb.32165

Moustakas M, Lanaras T, Symeonidis I, Karataglis S (1994) Growth and some photosynthetic characteristics of field grown Avena sativa under copper and lead stress. Photosynthetic 30(3):389-396.

Mujib A, Ali M, Tonk D, Zafar N (2017) Nuclear 2C DNA and genome size analysis in somatic embryo regenerated gladiolus plants using flow cytometry. Adv Hort Sci 31(3):165-174. doi:10.13128/ahs-21956 
Murashige T, Skoog F (1962) A revised medium for rapid growth and bioassays with tobacco tissue cultures. Physiol Plant 15(3):473-497. doi:10.1111/j.1399-3054.1962.tb08052.x

Nakano Y, Asada K (1981) Hydrogen peroxide is scavenged by the ascorbate-specific peroxidase in spinach chloroplasts. Plant Cell Physiol 22(5):867-880. doi:10.1093/oxfordjournals.pcp.a076232

Narain K (2004) - Garden life. Glorious gladioli. - The Tribune magazine. Spectrum.

http://www.tribuneindia.com/2004/20040905/spectrum/garden.htm.

Nic-Can GI, Galaz-Avalos RM, De-la-Peña C, Alcazar-Magaña A, Wrobel K, Loyola-Vargas VM (2015) Somatic embryogenesis: identified factors that lead to embryogenic repression: a case of species of the same genus. PLoS One 10:e0126414. doi:10.1371/journal.pone.0126414

Niedz R, Evens TJ (2007) Regulating plant tissue growth by mineral nutrition. In Vitro Cell Dev Biol - Plant 43(4):370-381. doi:10.1007/s11627-007-9062-5

Nirwan RS, Kothari SL (2003) High copper levels improve callus induction and plant regeneration in Sorghum bicolor (L.) Moench. In Vitro Cell Dev Biol - Plant 39(2):161-164. doi:10.1079/IVP2002385

Nomura T, Itouga M, Kojima M, Kato Y, Sakakibara H, Hasezawa S (2015) Copper mediates auxin signalling to control cell differentiation in the copper moss Scopelophila cataractae. J Exp Bot 66(5):1205-1213. doi:10.1093/jxb/eru470

Ochatt SJ, Revilla MA (2016) From stress to embryos: some of the problems for induction and maturation of somatic embryos. In: Germana M, Lambardi M (eds), In Vitro Embryogenesis in Higher Plants, Methods in Molecular Biology Vol. 1359. Humana Press, New York NY. doi:10.1007/978-1-4939-3061-6_31

Ozudogru EA, Ozden-Tokatli Y, Akcin A (2005) Effect of silver nitrate on multiple shoot formation of virginia-type peanut through shoot tip culture. In Vitro Cell Dev Biol - Plant 41(2):151-156.

doi:10.1079/ivp2004591

Parimalan R, Giridhar P, Ravishankar G (2011) Enhanced shoot organogenesis in Bixa orellana L. in the presence of putrescine and silver nitrate. Plant Cell Tiss Organ Cult 105(3):285-290.

doi:10.1007/s11240-010-9865-7

Parimalan R, Giridhar P, Ravishankar GA (2010) Enhanced shoot organogenesis in Bixa orellana L. in the presence of putrescine and silver nitrate. Plant Cell Tiss Organ Cult 105(3):285290. doi:10.1007/s11240-010-9865-7

Park EJ, Yi J, Kim Y, Choi K, Park K (2010) Silver nanoparticles induce cytotoxicity by a Trojan-horse type mechanism. Toxicol In Vitro 24(3):872-878. doi:10.1016/j.tiv.2009.12.001

Perl A, Aviv D, Galun E (1988) Ethylene and in vitro culture of potato: suppression of ethylene generation vastly improves protoplast yield, plating efficiency and transient expression of an alien gene. Plant Cell 
Rep 7(6):403-406. doi:10.1007/BF00269523

Petrova M, Zayova E, Vitkova A (2011) Effect of silver nitrate on in vitro root formation of Gentiana lutea. Rom Biotechnol Lett 16(6):53-58.

Piqueras A, Cortina M, Serna MD, Casas JL (2002) Polyamines and hyperhydricity in micropropagated carnation shoots. Plant Sci 162(5):671-678. doi:10.1016/S0168-9452(02)00007-9

Pontes MS, Graciano DE, Antunes DR, Santos JS, Arruda GJ, Botero ER, Grillo R, Lima SM, Andrade LH, Caires AR, Santiago EF (2020) In vitro and in vivo impact assessment of eco-designed CuO nanoparticles on non-target aquatic photoautotrophic organisms. J Hazard

Mater 396:122484. doi:10.1016/j.jhazmat.2020.122484

Popelka JC, Altpeter F (2001) Interactions between genotypes and culture media components for improved in vitro response of rye (Secale cereale L) inbred lines. Plant Cell Rep 20:575-582. doi:10.1007/s002990100369

Preece JE (1995) Can nutrient salts partially substitute for plant growth regulators. Plant Tiss Cult Biotechnol 1:26-37.

Purnhauser L, Gyulai G (1993) Effect of copper on shoot and root regeneration in wheat, triticale, rape and tobacco tissue cultures. Plant Cell Tiss Organ Cult 35:131-139. doi:10.1007/BF00032962

Rahmati Ishka M, Vatamaniuk OK (2020) Copper deficiency alters shoot architecture and reduces fertility of both gynoecium and androecium in Arabidopsis thaliana. Plant Direct 00:1-18. doi:10.1002/ pld3.28

Ramage CM, Williams RR (2002) Mineral nutrition and plant morphogenesis. In Vitro Cell Dev Biol-Plant 38(2):116-124. doi:10.1079/IVP2002269

Ravet K, Pilon M (2013) Copper and iron homeostasis in plants: the challenges of oxidative stress. Antioxidants Redox Signal 19(9):919-932. doi:10.1089/ars.2012.5084

Rego LV, de Faria RT (2001) Tissue culture in ornamental plant breeding: a review. Cropp Breed Applied Biotechnol 1(3):283-300. doi:10.13082/1984-7033.v01n03a09

Robson AD, Reuter DJ (1981) Diagnosis of copper deficiency and toxicity. Copp Soils Plants. http://agris.fao.org/agris-search/search. do? recordID=US8608668

Roh KH, Kwak BK, Kim JB, Lee KR, Kim HK, Kim SH (2012) The influence of silver thiosulfate and thidiazuron on shoot regeneration from cotyledon explants of Brassica napus. J Plant Biotechnol 39(3):133-139. doi:10.5010/JPB.2012.39.3.133

Rojas-Lorz L, Arrieta-Espinoza G, Valdez-Melara M, Pereira LFP, Gatica-Arias A (2019) Influence of silver nitrate on somatic embryogenesis induction in Arabica Coffee (Coffea arabica L.). Brazilian Archives Biol 
Roshanfekrrad M, Zarghami R, Hassani H, Zakizadeh H, Salari A (2017) Effect of $\mathrm{AgNO}_{3}$ and BAP on root as a novel explant in date palm (Phoenix dactylifera cv. Medjool) somatic embryogenesis. Pak J Biol Sci 20(1):20-27. doi:10.3923/pjbs.2017.20.27

Roustan JP, Latche A, Fallot J (1990) Control of carrot somatic embryogenesis by $\mathrm{AgNO}_{3}$, an inhibitor of ethylene action: effect on arginine decarboxylase activity. Plant Sci 67(1):89-95. doi:10.1016/01689452(90)90054-R

Rout GR, Mohapatra A, Jain SM (2006) Tissue culture of ornamental pot plant: a critical review on present scenario and future prospects. Biotechnol Adv 24(6):531560. doi:10.1016/j.biotechadv.2006.05.001

Sahrawat AK, Chand S (1999) Stimulatory effect of copper on plant regeneration in indica rice (Oryza sativa L.). J Plant Physiol 10(4):517-22. doi:10.1016/S0176- 1617(99)80292-2.

Sakhanokho HF, Kelley RY, Rajasekaran K (2008) First report of plant regeneration via somatic embryogenesis from shoot apex-derived callus of Hedychium muluense R. M. Smith. J Crop Imp 21(2):191-200. doi:10.1080/15427520701885758

Sakhanokho HF, Rajasekaran K, Kelley RY (2009) Somatic embryogenesis in Hedychium bousigonianum. HortScience 44(5):1487-1490. doi:10.21273/HORTSCI.44.5.1487

Sánchez-Viveros G, Ferrara-Cerrato R, Alarcón A (2011) Short-term effects of arsenate induced toxicity on growth, chlorophyll and carotenoid contents, and total content of phenolic compounds of Azolla filiculoides. Water Air Soil Pollut 217(1):455-462. doi:10.1007/s11270-010-0600-0

Shah SH, Ali S, Jan SA, Jalal-ud-din, Ali GM (2014) Assessment of silver nitrate on callus induction and in vitro shoot regeneration in tomato (Solanum lycopersicum Mill.). Pak J Bot 46(6):2163-2172.

Shelford VE (1913) Animal communities in temperate America, as illustrated in the Chicago region; a study in animal ecology. The Geographic Soceity of Chicago Bulletin 5(386):1877-1968. doi:10.5962/bhl.title.34437

Shelford VE (1931) Some concepts of bioecology. Ecol 12(3):455-467. doi:10.2307/1928991

Shioi Y, Tamai H, Sasa T (1978) Inhibition of photosystem II in green alga Ankistrodesmus falcatus by copper. Physiol Plant 44(4):434-438. doi:10.1111/j.1399-3054.1978.tb01651.x

Shkolnik MY (1984) Trace elements in plants. Elsevier, Amsterdam, p 463.

Silvestri C, Rugini E, Cristofori V (2019) The effect of $\mathrm{CuSO}_{4}$ for establishing in vitro culture, and the role nitrogen and iron sources in in vitro multiplication of Corylus avellana L. cv. Tonda Gentile Romana. Plant 
Biosystems - An Intl J Dealing with all Aspects of Plant Biol 154(5):1-7.

doi:10.1080/11263504.2018.1549610

Singh HP (2011) Paradigm in marketing of horticultural produce. Indian Hort 56(3):3-8.

Sirisom Y, Te-Chato S (2012) The effect of peptone and silver nitrate on in vitro shoot formation in Hevea brasiliensis Muell Arg. J Agric Technol 8(4):1509-1516.

Souza PVL, Lima-Melo Y, Carvalho FE, Reichheld J-P, Fernie AR, Silveira JAG, Daloso DM (2019) Function and compensatory mechanisms among the components of the chloroplastic redox network. Crit Rev Plant Sci 38(1):1-28. doi:10.1080/07352689.2018.1528409

Steinitz B, Barr N, Tabib Y, Vaknin Y, Bernstein N (2010) Control of in vitro rooting and plant development in Corymbia maculata by silver nitrate, silver thiosulfate and thiosulfate ion. Plant Cell Rep 29(11):13151323. doi:10.1007/s00299-010-0918-5

Strader LC, Beisner ER, Bartel B (2009) Silver ions increase auxin efflux independently of effects on ethylene response. Plant Cell 21(11):3585-3590. doi:10.1105/tpc.108.065185

Sunandakumari C, Martin KP, Chithra M, Madhusoodanan PV (2004) Silver nitrate induced rooting and flowering in vitro on rare rhoeophytic woody medicinal plant, Rotula aquatica Lour. Indian J Biotech 3(3):418-421.

Tahiliani S, Kothari SL (2012) Increased copper content of the medium improves plant regeneration from immature embryo-derived callus of Wheat (Triticum aestivum). J Plant Biochem Biotechnol 13:85-88. doi:10.1007/BF03263199

Tamimi SM (2015) Effects of ethylene inhibitors, silver nitrate $\left(\mathrm{AgNO}_{3}\right)$, cobalt chloride $\left(\mathrm{CoCl}_{2}\right)$ and aminooxyacetic acid (AOA), on in vitro shoot induction and rooting of banana (Musa acuminata L.). Afri J Biotechnol 14(32):2510-2516. doi:10.5897/AJB2015.14788

Tamimi SM, Othman H (2020) Effects of copper sulphate on shoot multiplication and rooting of banana (Musa acuminata L.) (In vitro study). Asian J Plant Sci 19(3):200-204. doi:10.3923/ajps.2020.200.204

Uliaie ED, Farsi M, Ghreyazie B, Imani J (2008) Effect of genotype and $\mathrm{AgNO}_{3}$ on shoot regeneration in winter cultivars of rapeseed (Brassica napus). Pakistan J Biol Sci 11(16):2040-2043. doi:10.3923/pjbs.2008.2040.2043

Vain P, Yean H, Flament P (1989) Enhancement of production and regeneration of embryogenic type II callus in Zea mays L. by $\mathrm{AgNO}_{3}$. Plant Cell Tiss Organ Cult 18(2):143-151. doi:10.1007/BF00047740

Venkatachalama P, Jinua U, Gomathia M, Mahendrana D, Ahmadc N, Geethad N, Sahi SV (2017) Role of silver nitrate in plant regeneration from cotyledonary nodal segment explants of Prosopis cineraria (L.) 
Druce.: a recalcitrant medicinal leguminous tree. Biocat Agric Biotechnol 12:286-291. doi:10.1016/j.bcab.2017.10.017

Verma JP, Singh V, Yadav J (2011) Effect of copper sulphate on seed germination, plant growth and peroxidase activity of mung bean (Vigna radiata). Int J Bot 7(2):200-204. doi:10.3923/ijb.2011.200.204

Watanabe S, Kojima K, Ide Y, Sasaki S (2000) Effects of saline and osmotic stress on proline and sugar accumulation in Populus euphratica in vitro. Plant Cell Tiss Organ Cult 63(3):199206. doi:10.1023/A:1010619503680

Weigel M, Varotto C, Pesaresi P, Finazzi G, Rappaport F, Salamini F, Leister D (2003) Plastocyanin is indispensable for photosynthetic electron flow in Arabidopsis thaliana. J Biological Chem 278(33):31286-31289. doi:10.1074/jbc.M302876200

Wellburn AR (1994) The spectral determinations of chlorophylls $a$ and $b$, as well as total carotenoids using various solvents with the spectrophotometers of different resolution. J Plant Physiol 144(3):307313. doi:10.1016/S0176-1617(11)81192-2

Wu LM, Wei YM, Zheng YL (2006) Effects of silver nitrate on the tissue culture of immature wheat embryos. Russian J Plant Physiol 53(4):530-34. doi:10.1134/S1021443706040157

Wu LM, Wei YM, Zheng YL (2006) Effects of silver nitrate on the tissue culture of immature wheat embryos. Russ J Plant Physiol 53(4):530-596. doi:10.1134/S1021443706040157

Yin LY, Cheng YW, Espinasse B, Colman BP, Auffan M, Wiesner M, Rose J, Liu J, Bernhardt ES (2011) More than the ions: the effects of silver nanoparticles on Lolium multiflorum. Environ Sci Technol 45(6):23602367. doi:10.1021/es103995x

Yruela I (2005) Copper in plants. Braz J Plant Physiol 17(1):145-156. doi:10.1590/S167704202005000100012

Zavattieri MA, Frederico AM, Lima M, Sabino R, Arnholdt-Schmitt B (2010) Induction of somatic embryogenesis as an example of stress-related plant reactions. Electronic J Biotechnol 13(1):12-13. doi:10.2225/vol13-issue1-fulltext-4

Zenk MH (1996) Heavy metal detoxification in higher plants-a review. Gene 179(1):21-30. doi:10.1016/S0378-1119(96)00422-2

Zhang P, Phansiri S, Puonti KJ (2001) Improvements of cassava shoot organogenesis by the use of silver nitrate in vitro. Plant Cell Tiss Organ Cult 67(10):47-54. doi: 10.1023/A:1011654128198

Ziv M, Halevy AH, Shilo R (1970) Organs and plantlets regeneration of Gladiolus through tissue culture. Ann Bot 34(136):671-676. 


\section{Figures}

\section{Figure 1}

a Callus induction from corm explants, $\mathbf{b}$ embryogenic tissue formation and proliferation, $\mathbf{c}-\mathbf{i}$ embryos induction, proliferation and maturation, $\mathbf{j}-\mathbf{k}$ mature somatic embryos germination, $\mathbf{I - n}$ shoot morphogenesis from callus, o-p mature somatic embryos germination, q-s mature embryos germination in singularity forms, $\mathbf{t - u}$ multiple shoot morphogenesis, $\mathbf{v - x}$ rhizogenesis on medium amended with $\mathrm{CuSO}_{4} \cdot 5 \mathrm{H}_{2} \mathrm{O}, \mathrm{AgNO}_{3}$ and $\mathrm{CuSO}_{4} \cdot 5 \mathrm{H}_{2} \mathrm{O}+\mathrm{AgNO}_{3}$, $\mathbf{y}$ treatment of the shoots with $60 \mu \mathrm{M} \mathrm{AgNO}_{3}$ on root morphogenesis medium, $\mathbf{z}$ aclimatized Gladiolus hybridus plants after 4 weeks cultivation. Arrowheads show somatic embryos induction or shoot morphogenesis.
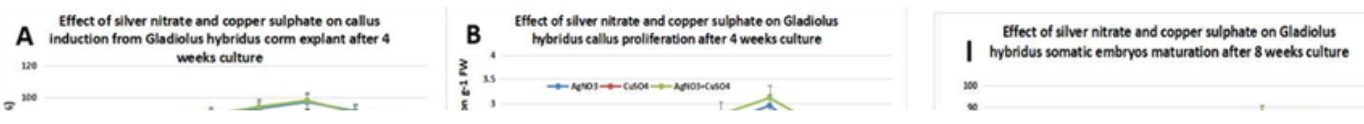

Effect of silver nitrate and copper sulphate on Glodiolus hybridus mature somatic embryos $\sigma^{100}$

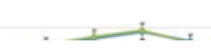

s. $\infty$ germination after 6 weeks culture

\section{Figure 2}

Influence of silver nitrate and copper sulphate on in vitro morphogenesis in G. hybridus. 


\section{Figure 3}

Influence of $\mathrm{CuSO}_{4} \cdot 5 \mathrm{H}_{2} \mathrm{O}$ and $\mathrm{AgNO}_{3}$ on the expression of antioxidant systems and pigment molecules during in vitro morphogenesis (somatic embryogenesis and shoot morphogenesis) in G. hybridus. 